\title{
JOHN MARSHALL'S "JEFFERSONIAN" CONCEPT OF JUDICIAL REVIEW
}

\author{
DAVID E. ENGDAHL $\dagger$
}

INTRODUCTION . . . . . . . . . . . . . . . . . . . . 279

I. The PRACTICE "WeLl Established"

BEFORE 1800 . . . . . . . . . . . . . . . . . 282

II. CiRCUMSTANCES GENERATING EARLY CONFIDENCE IN COURTS . . . . . . . . . . . . . . . . . . . . . 289

III. THE CONTROVERSY OVER JUDICIAL SUPREMACY DuRING THE LATE 1790 . . . . . . . . . . . . . . . 297

IV. JOHN MARSHALL'S CONCEPT IN $1800 \ldots \ldots \ldots \ldots$. . 304

V. JOHN MARSHALL'S CONCEPT IN $1801 \ldots \ldots \ldots \ldots \ldots$.

VI. THE CONTROVERSY DURING $1802 \ldots \ldots \ldots \ldots \ldots .318$

VII. JOHN MARSHALL'S CONCEPT IN 1803: MARBURY V.

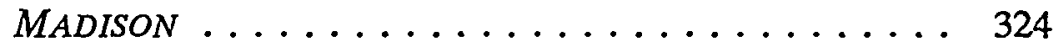

VIII. CONCLUSION . . . . . . . . . . . . . 333

\section{INTRODUCTION}

The proposition that courts should disregard unconstitutional laws was common ground among advocates and commentators during our nation's founding period. Some even asserted that enforcing constitutional limits was peculiarly the judiciary's task. But there were changes enough during the first decade under the Constitution that, well before Thomas Jefferson became President in 1801, reliance upon courts to resolve constitutional questions had become controversial. Originally, "judicial supremacy" had been easily and widely (if not casually) endorsed; but subsequently, it became chiefly a doctrine of Federalist partisans, while Jefferson followed James Madison in pursuing more careful reasoning to a distinctly different view.

This Article closely examines some neglected data that induce a highly unorthodox conclusion: When he wrote the Supreme

$\dagger$ Professor, University of Puget Sound School of Law. LL.B. 1964, University of Kansas; S.J.D. 1969, University of Michigan. 
Court's opinion in Marbury v. Madison in $1803,{ }^{1}$ Chief Justice John Marshall did not share the Federalist "judicial supremacy" view, but instead agreed with Jefferson and Madison. His opinion in Marbury states not the Federalist, but the "Jeffersonian" concept of the practice now commonly called "judicial review."

Actually, it indulges imprecision for the sake of convenient expression to say that Marshall held the "Jeffersonian" view. We shall learn that Marshall employed the view as a member of the Sixth Congress in March of 1800, whereas Jefferson's first known articulation of it was in December of 1801. Moreover, Madison's first relevant statements antedated Marshall's and Jefferson's by more than ten years. Exactly when any of these three Virginians (or others of like mind from Vermont to Georgia) might have come to this view, and whether they came to it independently or derived it from some common source, are simply impossible to know. However, among constitutional scholars the view that each organ of government is obliged to decide independently such constitutional questions as might arise in the course of its work, none being bound by the others' opinions on the same question ${ }^{3}$ (unless

1. 5 U.S. (1 Cranch) 137 (1803).

2. Robert Clinton explains that ' 'Judicial review,' as a term . ... , apparently was an invention of law writers in the early twentieth century. Edward S. Corwin may have been the first to coin the phrase, in the title of an article in the 1910 Michigan Law Review." ROBERT L. ClINTON, MARBURY V. MADISON AND JUDICIAL REVIEW 7 (1989).

3. This often is characterized as "concurrent review," see, e.g., CHRISTOPHER WOLFE, THE RISE OF. MODERN JUdiCIAL REVIEW 94 (1986); Wallace Mendelson, Jef. ferson on Judicial Review: Consistency Through Change, 29 U. CHI. L. REV. 327, 327 (1962), but no shorthand label is sufficient to communicate the idea and preclude misconceptions. 
as parties in litigation by res judicata), ${ }^{4}$ is considered "Jeffersonian"; and therefore that label is used here.

This "Jeffersonian" view is further elaborated in the course of this Article; attempting a better synopsis at this stage would distort it. ${ }^{5}$ The critical point regarding the "Jeffersonian" view is its contrast with the Federalist "judicial supremacy" view that constitutional interpretation is peculiarly judicial business (except as to, e.g., "political questions") and that Supreme Court decisions on constitutional questions are not merely binding for the particular parties and case but are authoritative generally and for all. The classic modern articulation of judicial supremacy is Cooper $v$.

4. The "Jeffersonian" concept is easily mistaken and misstated. It does not contemplate defiance of judicial orders, or disregard of the principle of res judicata; thus it cannot be fairly characterized as "arbitrary review," as suggested by Clinton. See CuINTON, supra note 2, at 25-26.

In addition to overlooking the principle of res judicata, Clinton seems to have been too concerned "over who has the power to give a final authoritative interpretation of the Constitution." Id. at 25. The "Jeffersonian" answer, of course, is that no one in the government has that power, or need have it. As Samuel Krislov wrote a generation ago,

[Jefferson] was not worried by the problem that would arise from the lack of a

final authority .... [H]e preferred finality to rest with no one.

It can be seen, then, why the Jeffersonian position has been so misunder-

stood. The idea of a political system with no final and efficient determinant of constitutional meaning grates strangely on American ears.

Samuel Krislov, Jefferson and Judicial Review: Refereeing Cahn, Commager and Mendelson, 9 J. PUB. L. 375, 378 (1960).

5. The thesis here is only that this one "Jeffersonian" concept was shared by John Marshall. Generally anything but enthusiastic about Jefferson, Marshall had very different ideas about many (or most) things.

Obviously, for example, he never indulged the Jeffersonian nonsense that federal courts lack jurisdiction to review federal question decisions of state courts. See WOLFE, supra note 3, at 95. I must postpone to a later article the demonstration that review of such state decisions by one or another federal tribunal (not necessarily the Supreme Court, unless Congress should opt to create no other tribunal) was deliberately ensured by the Framers. The particular scheme for such review elected by Congress in the Judiciary Act of 1789 , ch. $20, \& 25,1$ Stat. 73,85 , had been practiced without challenge for decades before it came into question when Virginia judges, apparently seduced by Jeffersonian states' rights ideology, presumed not only to disobey a Supreme Court mandate but to assert competence to declare $\S 25$ unconstitutional. The extravagant errors of Justice Story's argument in Martin v. Hunter's Lessee, 14 U.S. (1 Wheat.) 304 (1816) are superfluous to the matter, see, e.g., Justice Johnson's concurring opinion in Martin, id. at 362-82, but it should not be imagined that Chief Justice Marshall ever countenanced the Jeffersonian view on that jurisdictional issue. 
Aaron, ${ }^{6}$ notable (if the thesis of this Article holds) for its flagrant misrepresentation of Marshall's Marbury view.

\section{The PRactice "Well Established" Before 1800}

Several state courts before 1787 had disregarded state measures as unconstitutional. ${ }^{7}$ Although such holdings had sometimes

6. 358 U.S. 1 (1958). This was the Little Rock school desegregation case, for which the Court held an extraordinary August Special Term. The opinion, unlike any other in the Court's history, is captioned the "Opinion of the Court by" each of the Justices, who are each separately listed by name as its authors. They wrote:

In 1803, Chief Justice Marshall . . . declared in the notable case of Marbury v. Madison ... that "It is emphatically the province and duty of the judicial department to say what the law is." This decision declared the basic principle that the federal judiciary is supreme in the exposition of the law of the Constitution, and that principle has ever since been respected by this Court and the Country as a permanent and indispensable feature of our constitutional system. It follows that the interpretation of the Fourteenth Amendment enunciated by this Court in [a particular case] . . . is the supreme law of the land, and Art. VI of the Constitution makes it of binding effect on the States [even though non-parties] "any Thing in the Constitution or Laws of any State to the Contrary notwithstanding" [quoted from the Supremacy Clause]. Every state legislator and executive and judicial officer is solemnly committed by oath taken pursuant to Art. VI, cl. 3, "to support this Constitution."

Id. at 18 (citations omitted). In other words, every official is oath-bound to support, in every possible application, the interpretation of the Constitution enunciated by the Supreme Court!

Historically, the classic articulation of this view was not by John Marshall, but by Joseph Story, who wrote:

[R]easoning from the terms of the constitution, and the known principles of our jurisprudence, the appropriate conclusion is, that the judicial department of the United States is, in the last resort, the final expositor of the constitution, as to all questions of a judicial nature ....

JOSEPH STORY, COMMENTARIES ON THE CONSTITUTION OF THE UNITED STATES 360 (1st ed. 1833).

7. The best examples are from Virginia and North Carolina:

A. Commonwealth v. Caton, 8 Va. (4 Call) 5 (1782), reprinted in 1 BERNARD SCHWARTZ, THE BILL OF RIGHTS: A DOCUMENTARY HISTORY 410 (1971). A purported pardon was held invalid as having been granted contrary to terms of the constitution, although the wording of the constitutional provision necessitated considerable reasoning to reach a sound construction. See Suzanna Sherry, The Founders' Unwritten Constitution, 54 U. CHI. L. REv. 1127, 1143-45 (1987).

B. Bayard v. Singleton, 1 N.C. (1 Mart. 48 ) 42 (1787), reprinted in 1 ScHWARTZ, supra, at 429. The judges separately but unanimously held unconstitutional a statute directing dismissal of cases brought to recover lands claimed by virtue of sale by the state's commissioners of confiscated estates, on affidavit of the fact of such sale. The state constitution expressly guaranteed "in all controversies at law, respecting property, the ancient mode of trial, by jury . . . " N.C. CONST. of 1776, art. XIV, reprinted in 5 Francis N. Thorpe, The Federal and State Constitutions, Colonial Charters, and OTHER ORganic laws OF the States, TERRITORIES aND Colonies Now OR HERETOFORE FORMING THE UNITED STATES OF AMERICA 2787 (1909); see Sherry, supra, at 1143. 


\section{stirred controversy, ${ }^{8}$ delegates to the Constitutional Convention at}

These other examples are subject to some degree of dispute:

C. Holmes v. Walton, an unreported New Jersey case from 1780 , discussed in Wayne D. Moore, Written and Unwritten Constitutional Law in the Founding Period: The Early New Jersey Cases, 7 ConstTTUTIONAL COMMENTARY 341 (1990); Austin Scott, Holmes v. Walton: The New Jersey Precedent, 4 AM. HIST. REv. 456 (1899), reprinted in 1 SCHWARTZ, supra, at 405 . Apparently a case of major proportions tried pursuant to a statute specifying a jury of six was reversed on review in light of the state constitution's guarantee of "the inestimable right of trial by jury," N.J. CONST. of 1776, even though the constitutional text did not specify twelve. See Sherry, supra, at 1141.

D. The "Ten Pound Act" Cases, New Hampshire court decisions from late 1786 and 1787. See 2 WILliam W. CROSSKEY, POLITICS AND THE CONSTITUTION IN THE HISTORY OF THE UNITED STATES 968-70 (1953). The judges apparently held unconstitutional an act directing trials without jury in actions demanding ten pounds or less in debt or for trespass not involving title to land; the constitution guaranteed jury trial except where "[t]heretofore otherwise used and practiced." N.H. CoNST. of 1783, pt. 1, art. 20. Apparently the judges insisted the exception only contemplated cases worth less than forty shillings. See Sherry, supra, at 1142.

E. Rutgers v. Waddington, an unreported decision of the New York City Mayor's Court from 1784, reprinted in 1 JULIUS GOEBEL, THE LAW PRACTICE OF ALEXANDER HAMILTON: DOCUMENTS AND COMMENTARY 393-419 (1964); discussed in JULIUS GOEBEL, 1 HISTORY OF THE SUPREME COURT OF THE UNITED STATES: ANTECEDENTS AND BEGINNINGS To 1801, at 132-37 (Paul A. Freund gen. ed., 1971) [hereinafter GOEBEL, ANTECEDENTS]; see 1 JAMES B. THAYER, CASES ON CONSTTTUTIONAI LAW 63-72 (Cambridge, Mass., G.H. Kent 1895). It was argued that a state statute should be disregarded as contrary to the law of nations and to a treaty concluded under the Articles of Confederation, although the latter had no explicit "supremacy" clause. See Sherry, supra, at $1136-38$.

F. Trevett v. Weeden, a pamphleted decision of Rhode Island's Superior Court of Judicature from 1786. See JAMES M. VARNUM, THE CASE, TREVETT V. WEEDEN (1787); reprinted in 1 SCHWARTZ, supra, at 417; discussed in 2 PELEG W. CHANDLER, CRIMINAL TRIALS 268 (1844); GOEBEL, ANTECEDENTS, supra, at 137-41. Appatently the judges had debatable reasons for considering unconstitutional a statute contemplating trials without jury for refusals to accept par tender of paper money. See Sherry, supra, at 1138-41.

8. In North Carolina, proposals in the legislature to mstruct the judges to treat the constitution and statutes in parity, and to sanction thein for doing otherwise, failed. In New Hampshire, impeachment was considered but rejected; instead, the legislature repealed the offending law. In New York, legislators condemned the mayor's court but defeated a motion to remove the mayor from office. See RAOUL BERGER, CoNGRESS v. THE SUPREME COURT 42 (1969). In Rhode Island, the legislature called the judges to account for their decision but took no action; at the next election however, all but one of the judges were voted out. See GOEBEL, ANTECEDENTs, supra note 7, at 140-41.

In Virginia, the judges protested against a 1787 judicial reorganization statute they deemed unconstitutional in certain respects, Remonstrance of Virginia Court of Appeals, 8 Va. (4 Call) 135 (1788), summarized by Congressman John Randolph, Jr., Republican from Virginia, in 11 ANNALS OF CONG. 655 (1802); and the legislature, specially convened by the governor, therefore suspended the act, see St. George Tucker, Appendix to 4 William Blackstone, COMMENTARIES, app. 12 (St. George Tucker ed., Philadelphia, Birch \& Small 1803). The next year judicial reform was considered again; but as legislator James Monroe wrote to his friend James Madison, while " $[t]$ he arrangement of the Judiciary is the principal subject before the house ... [i]t has been agreed by all to pass 
Philadelphia evidently assumed that courts as a matter of course would disregard unconstitutional acts. ${ }^{9}$ The proposition that they should was discussed favorably at several ratifying conventions. ${ }^{10}$ It therefore seems significant that of all the amendatory provisions proposed at those conventions, although several were aimed at

by the question 'whether the Judiciary may declare a law, in their opinion agnst the Constitution, void,' as calculated to create heats $\&$ animosities that will produce harm." Letter from James Monroe to James Madison (Nov. 22, 1788), in 1 THE WRITINGS OF JAMES MONROE 196 (Stanislaus M. Hamilton ed., 1898).

9. One reason against including judges in the veto function was agreement that they should evaluate the constitutionality (although not the policy) of measures in the litigation process. See 1 RECORDS OF THE FEDERAL CONVENTION OF 1787, at 93-114, 130-47 (Max Farrand ed., 1911) [hereinafter RECORDS]; 2 id. at 21-36, 71-83.

Among delegates who made it explicit that judges should test measures against the Constitution were Gouverneur Morris of Pennsylvania, 2 id. at 28; Luther Martin of Maryland, 2 id. at 76; James Madison and George Mason of Virginia, 2 id. at 27, 78; and Elbridge Gerry and Rufus King of Massachusetts, 1 id. at 97, 109. Virginia delegates George Wythe and John Blair, judges at home, already had done so with laws of their state. See Commonwealth v. Caton, 8 Va. (4 Call) 5 (1782); Remonstrance of Virginia Court of Appeals, $8 \mathrm{Va}$. (4 Call) 135, 141-42 (1788). Madison adverted to the Rhode Island example as illustrating the need to assure the independence of judges. 2 RECORDS, supra, at 27-28.

Yates of New York and Martin of Maryland specified anticipation of such actions by judges among their reasons for opposing the Constitution. As to Yates, see THE ANTIFEDERALIST PAPERS 222-40 (Morton Borden ed., 1965); BERGER, supra note 8, at 201-02. As to Martin, see his Genuine Information delivered to the Maryland House of Delegates on Nov. 28, 1787, 3 RECORDS, supra, at 172, 220, 222, also published in 1 ELLIOT'S DEBATES 344, 380, 382 (Johnathan Elliot ed., 2d ed. 1836).

10. A handful of relevant excerpts from the Constitutional Convention and the ratification era are conveniently printed in William W. Van Alstyne, A Critical Guide to Marbury v. Madison, 1969 DUKE L.J. 1, 38-45. From his exhaustive review of the ratification debates, Raoul Berger concluded that the proposition that courts should disregard unconstitutional enactments "met with no opposition and, indeed, as in Virginia, found enthusiastic concurrence." BERGER, supra note 8, at 143.

Those affirming the proposition include Samuel Adams in Massachusetts, 2 Elliot's DEBATES, supra note 9, at 131; 1 id. at 137 (1st ed. 1827); Oliver (later Senator and Chief Justice) Ellsworth in Connecticut, 2 id. at 196 (2d ed. 1836); Edmund Pendleton, 3 id. at 299, 302-03, 548 (2d ed. 1836); 2 id. at 231, 233-234 (1st ed. 1828); and John (later Chief Justice) Marshall in Virginia, $3 \mathrm{id}$. at 553-54 (2d ed. 1836); $2 \mathrm{id}$. at 404 (1st ed. 1828); and James (later Associate Justice) Wilson in Pennsylvania, 2 id. at 445-46, 489 (2d ed. 1836); 3 id. at 245 (1st ed. 1830).

In Virginia, Patrick Henry considered judicial resistance to unconstitutional acts essential and sought assurances (which were forthcoming) that "your federal judiciary will act thus?" 3 id. at 324-25 (2d ed. 1836); 2 id. at 248 (1st ed. 1828). In Pennsylvania, Wilson was indignant at opponents' suggestions that judges be impeachable for decisions against statutory law. See 2 id. at 478 (2d ed. 1836); 3 id. at 271 (1st ed. 1830). Shortly thereafter, in his 1790-1791 Lectures on Law, Wilson again strongly insisted that judges must disregard laws they deemed unconstitutional. See 1 THE WORKS OF JAMES WILSON 300, 326-31 (Robert G. McCloskey ed., 1967) [heremafter WORKS OF WILSON]. 
anticipated judicial abuses, none undertook to foreclose courts from considering whether acts of another branch were constitutional (and disregarding those acts they concluded were unconstitutional).

Jefferson himself highly praised Virginia's judges for having disregarded state legislation found to be at odds with the state constitution; and his assumption that courts would perform likewise with respect to the federal Constitution was advanced by him as a principal reason for adding a "bill of rights" by amendment. ${ }^{\text {11 }}$

Members of the first session of Congress under the Constitution affirmed that judges should consider and decide constitutional questions, ${ }^{12}$ and even considered how best to facilitate their doing

11. Madison had written to Jefferson (who was in France) in October 1788, discussing the controversial question whether the Constitution (then pending ratification) should be amended by addition of a "bill of rights" and venturing such reasons as he could in favor of the idea. Letter from James Madison to Thomas Jefferson (Oct. 17, 1788) [hereinafter Letter from Madison to Jefferson], in 11 THE PAPERS OF JAMES MADISON 295 (U. Va. Press 1977) [hereinafter PAPERS OF MADISON]. Jefferson answered:

In the arguments in favor of a declaration of rights, you omit one which has great weight with me, the legal check which it puts into the hands of the judiciary. This is a body, which if rendered mdependent, and kept strictly to their own department merits great confidence for their learning and integrity. In fact what degree of confidence would be too much for a body composed of such men as Wythe, Blair, and Pendleton? On characters like these the "civium ardor prava jubentium" would make no impression.

Letter from Thomas Jefferson to James Madison (Mar. 15, 1789), in 14 THE PAPERS of THOMAS JEFFERSON 659 (Julian P. Boyd ed., 1958) [hereinafter PAPERS OF JEFFERSON].

12. Speaking of the judges, Congressman Elbridge Gerry of Massachusetts stated: "The Constitution will undoubtedly be their first rule; and so far as your laws conform to that, they will attend to them, but no further." 1 ANNALS OF CONG. 829 (Joseph Gales ed., 1789).

Eleven weeks earlier, the issue was whether to include in the bill to establish the Department of Foreign Affairs a clause declaring the Department's chief officer reinovable by the President alone. A few said impeachment was the only removal means constitutionally allowed; others argued that removal, like appointinent, required Senate consent; others urged that unilateral presidential action was another, and, soine urged, the only, means of removal constitutionally allowed. Proponents of the last view disagreed whether the clause in the bill specifying presidential removal was superfluous, or was desirable (or even essential) as a legislative pronouncement on the constitutional point. Id. at $455-576$.

Spokesmen for all sides assumed courts would rule on the constitutional question if and when it should come before them. Abraham Baldwin of Georgia, for example, said: "Gentlemen say it properly belongs to the Judiciary to decide this question. Be it so. It is their province to decide upon our laws; and if they find them to be unconstitutional, they will not hesitate to declare it so .... Id. at 560. And Peter Sylvester of New York said: "It is certain that the Judiciary will be better able to decide the question of constitutionality in this way than any other. If we are wrong, they can correct our er- 
$\mathrm{so}^{13}$; and once they were created, the federal courts promptly began to do as had been anticipated. ${ }^{14}$ In the dozen or so years before Marbury v. Madison, constitutional questions were decided in the federal Circuit Courts on at least a score of known occasions. ${ }^{15}$ Reliable information was scarce even then; but Congress

ror ...." Id. at 562 .

In the tedious four days of debate on the clause, attention being focused on the constitutional issue and many speakers discussing the judicial role, no one confided the slightest doubt that courts should rule on the constitutionality of legislative or executive acts. The doubt expressed was only as to whether and how the question could make its way to the courts. Most seem to have understood that judges could opine only if the question arose in litigation. Congressinan Gerry, however, referred to the constitutional provision "which authorizes the President to obtain the opinions of the heads of departinents in writing," id. at 504-05, apparently failing to notice that it applies only to the heads of "executive" departments, see U.S. CoNST. art. II, $\$ 2$, cl. 1.

13. Supporters said that including the removal clause in tbe Act would facilitate judicial determination of constitutional questions. Abraham Baldwin of Georgia suggested that "it seems to be a very difficult point to bring before them in any other way." 1 ANNALS OF CONG., supra note 12, at 560 . Whether and by what process the question might be brought to a court was necessarily uncertain at that time; for the bill to organize the judiciary was just beginning to be considered by the whole Senate. Only a few House members had even seen the Senate Committee draft, and none had had time to study it. The judiciary bill would not reach final form until three months later.

William Smith of South Carolina and Baldwin of Georgia assumed that an officer thinking himself unconstitutionally removed could bring the question to court by seeking a writ of mandamus, id. at 459, 560; but Theodore Sedgwick of Massachusetts remarked that "doubt and difficulty" would surround such questions as against whom the mandamus should be directed, and whether the President could be compelled to answer such a suit, $i d$. at 523. Elias Boudinot of New Jersey warned that "[t]here will be some indelicacy in subjecting the Executive action in this particular to a suit at law." Id. at 470.

Madison was anong those who could "not see in what way this question could come before the judges, to obtain a fair and soleunn decision," id. at 501; but his doubt elicited a vigorous response from South Carolina's William Smith, who declared: "That gentleman is no stranger to a just and venerable law maxim. Wherever a man has a right, he has a remedy; if he suffers a wrong, he can have a redress; he would be entitled to damages for being deprived of his property in his office." Id. at 510 .

14. The President in April 1790 solicited the Justices' views concerning how the judiciary was structured by the 1789 Judiciary Act. Chief Justice John Jay circulated a draft response to the Associate Justices; it was later published in STORY, supra note 6, at 438-41, which attributed earlier publication to the American Jurist, see 4 AMERICAN JURIST 293-98 (1830). Jay maintained in his letter that the 1789 Act in some particulars, including its assignment of the same persons to sit both on the Circuit Courts and on the Supreme Court, was unconstitutional.

Apparently the letter never was forwarded to the President, although at least one Justice, Cushing, concurred in it. See GOEBEL, ANTECEDENTS, stupra note 7, at 556. It might be that Justices Wilson, Blair, and Rutledge, from having attended the Constitutional Convention (and Blair also from having served many years in a comparable state scheme), knew Jay's constitutional point lacked merit.

15. See infra note 17 and accompanying text. Because of lost records and the common use of unwritten rulings, we cannot discover how many more such decisions there 
was aware of at least some of the cases, and affirmed the practice they represented. ${ }^{16}$ Sometimes state measures, and sometimes acts of federal executive officials, were disregarded as unconstitutional in the Circuit Court cases. Occasionally, the constitutionality of federal statutes was scrutinized as well. ${ }^{17}$

Several of the Justices at Circuit, and in 1794 all of them together as the Supreme Court, held Congress's 1792 Pension Act unconstitutional ${ }^{18}$ yet even that was not the first time the Justices

may have been.

16. For example, Virginia Congressman John Nicholas noted in 1798: "Did not the Judiciary consider the acts of the Executive and Legislature? Certainly they did. There were instances in which the judges had decided upon the Constitution and laws of the country, and in one instance, he believed they had determined for them, and in another against them." 7 ANNALS OF CONG. 924 (1798). And James Bayard of Delaware answered:

Even the Judges, the gentleman said, are a check upon the Legislature. This arises from the nature of the Legislature, the powers of which are limited. If the Legislature transgress the bounds of their authority, their acts are void, and neither the people nor the Judges are bound by them.

8 id. at 1221.

17. See Ogden v. Witherspoon, 18 F. Cas. 618 (C.C.D.N.C. 1802) (No. 10,461); The Ulysses, 24 F. Cas. 515 (C.C.D. Mass. 1800) (No. 14,330); United States v. Callender, 25 F. Cas. 239 (C.C.D. Va. 1800) (No. 14,709); Case of Fries, 9 F. Cas. 924 (C.C.D. Pa. 1800) (No. 5127); Case of Fries, 9 F. Cas. 826 (C.C.D. Pa. 1799) (No. 5126); Pettibone v. Barber, unreported (C.C.D. Vt. 1798), discusscd in GOEBEL, ANTECEDENTS, supra note 7, at 591-92; Minge v. Gilmour, 17 F. Cas. 440 (C.C.D.N.C. 1798) (No. 9631); Lyon's Case, 15 F. Cas. 1183 (C.C.D. Vt. 1798) (No. 8646); United States v. Villato, 2 U.S. (2 Dall.) 370, 28 F. Cas. 377 (C.C.D. Pa. 1797) (No. 16,622); VanHorne's Lessee v. Dorrance, 2 U.S. (2 Dall.) 304, 28 F. Cas. 1012 (C.C.D. Pa. 1795) (No. 16,857); Skinner v. May, unreported (C.C.D. Mass. 1794), discussed in GOEBEL, ANTECEDENTS, supra note 7, at 589-90; Anonymous, unreported (C.C.D. Conn. 1793), discussed in 1 CHARLES WARREN, THE SUPREME COURT IN UNITED STATES HISTORY $68 \mathrm{n} .3$ (rev. ed. 1922); Higginson v. Greenwood, unreported (C.C.D.S.C. 1793), discussed in 1 WARREN, supra, at 66 n.1; Champion v. Casey (or Carey), unreported (C.C.D.R.I. 1792), discussed in 1 WARREN, supra, at 66-68, and in GOEBEL, ANTECEDENTS, supra note 7, at 589; Brailsford v. Spalding, unreported (C.C.D. Ga. 1792), discussed in 1 WARREN, supra, at 66 n.1; United States v. Smith, 27 F. Cas. 1147 (C.C. Mass. 1792) (No. 16,323); Murray v. Marean, unreported (C.C.D. Mass. 1791), discussed in DWIGHT F. HENDERSON, COURTS FOR A NEW NATION 78 (1971); Anonymous, unreported (C.C.D. Conn. 1791), discussed in 1 WARREN, supra, at 65-66, and in HENDERSON, supra, at 77-78; Emory v. Greenough, $8 \mathrm{~F}$. Cas. 685 (C.C.D. Mass. no date reported) (No. 4471); Jones v. Walker, 13 F. Cas. 1059 (C.C.D. Va. no date reported) (No. 7507); see also the Pension Act rulings discussed infra note 18.

18. The 1792 Pension Act directed Circuit Courts to judge veterans' disability pension claims, subject to review by the Secretary of War and Congress. Act of Mar. 23, 1792, ch. 11, 1 Stat. 243. Five Justices joined respectively with District Judges at Circuit to hold that Article III duties presume complete independence of judgment; that independence is lacking in decisions subject to executive or congressional review; and that therefore the duty given them by the Pension Act was not constitutionally within their "judi- 
cial Power." See 1 WARREN, supra note 17, at 70-71; Wilfred J. Ritz, United States v. Yale Todd (U.S. 1794), 15 WASH. \& LEE L. REV. 220, 223-24 (1958). The opinion of the Circuit Court for New York, and letters from the Circuit Courts for Pennsylvania and North Carolina, appear in a footnote to Hayburn's Case. 2 U.S. (2 Dall.) 409, 410 n.2 (1792). The President forwarded these views to Congress, see GOEBEL, ANTECEDENTS, supra note 7 , at 561 , which therefore established a different procedure for screening such claims, Act of Feb. 28, 1793, ch. 17, 1 Stat. 324.

Then the Supreme Court considered the issue in two cases at its February 1794 Term. The Attorney General brought the first, Uniled States $v$. Todd, as a collection action on behalf of the United States, to recover sums paid under an award certified by Chief Justice Jay, Justice Cushing, and Connecticut District Judge Law, who for the purpose had purported to act as "commissioners," rather than in their judicial capacity. Todd was an original action under a statute specially directing the Attorney General to seek a Supreme Court ruling on the point. Act of Feb. 28, 1793, § 3, 1 Stat. 324; see 1 WARREN, supra note 17 , at $77-83$.

The second case, Motion of Chandler, was an original mandamus action to compel the Secretary of War to place the claimant on the pension list "conformably to the Order and Adjudication of the Honorable James Iredell and Richard Law Esquires Judges of the Circuit Court of the United States." Motion of Chandler (Feb. 5, 1794), in Erwin C. Surrency ed., The Minutes of the Supreme Court of the United States 1789-1806, 5 AM. J. LEGAL HIST. 166, 188-89 (1961) [hereinafter Minutes]. Actually, Iredell and Law, refusing to consider it in their judicial capacity like the judges in Todd, had certified Chandler's claim purportedly as "commissioners." The Supreme Court, however, would have to consider the case as pleaded, and the pleadings alleged an "Order and Adjudication" of "Judges of the Circuit Court."

In both cases the Court held the awards invalid. In neither was any opinion written; both are known only from sparse Supreme Court uninutes, not published until 1961. United States v. Tod [sic] (Feb. 17, 1794), in Minutes, supra, at 195-96; Motion of Chandler, (Feb. 5, 1794), in Minutes, supra, at 188-89. The definitive source now is 1 THE DOCUMENTARY HISTORY OF THE SUPREME COURT OF THE UNITED STATES, 1789-1800, at 222, 228, 375, 380, 494 (Maeve Marcus \& James R. Perry eds., 1985); see also Gordon E. Sherman, The Case of John Chandler v. The Secretary of War, 14 YALE L.J. 431, 435 (1905) (also listing the Supreme Court minutes).

Because of the scant records, notable commentators have denied that these were constitutional decisions at all. See, e.g., GOEBEL, ANTECEDENTS, supra note 7, at 565; 1 WARREN, supra note 17, at 81, $81 \mathrm{n} .2$; David P. Currie, The Constitution in the Supreme Court: 1789-1801, 48 U. CHI. L. REV. 819, 825-28 (1981). But those commentators surely are wrong. The Chandler minutes recite merely that "the Court . . a are of opinion that a Mandamus cannot issue to the Secretary of War for the purposes expressed in the said motion." Motion of Chandler (Feb. 14, 1794), in Minutes, supra, at 193. Because Chandler's counsel insisted that the award was an "Order and Adjudication" of "Judges of the Circuit Court" even though the judges themselves (including Justice Iredell) explicitly had deemed themselves acting only as commissioners, 1 WARREN, supra note 17 , at 80 \& n.1; Sherman, supra, at 433, unless the pleadings were ignored, the Supreme Court must have considered their authority to certify the claim in either capacity. If so, the constitutional point could not have been avoided.

Marshall noted in Marbury v. Madison, 5 U.S. (1 Cranch) 137, 171-72 (1803), that the refusals by Justices at Circuit to perform Pension Act duties in a judicial capacity had been articulated on constitutional grounds. Furthermore, the Marbury Court included Justice Paterson-a participant nine years earlier in both Chandler and Todd-who seems to have shared Marshall's view that the 1794 cases were decided on constitutional 
discussed, as a group, judicial determination of constitutional questions. ${ }^{19}$ And even before the original Justices had accumulated much official work to do, James Wilson, the most respected for scholarship among them, had taken pains in his 1790-1791 Law Lectures to explain why courts must decide constitutional points-even exulting, "What a noble guard against legislative despotism!'20

Unsurprisingly, therefore, John Marshall observed in Marbury v. Madison that the principles on which courts base their disregard of statutes they find unconstitutional were "long and well established"21 prior to that 1803 case.

\section{Circumstances Generating EARLY CONFIDENCE IN COURTS}

The widespread enthusiasm prevailing well into the 1790 s for judicial resolution of constitutional questions seems to have been chiefly attributable to three circumstances, for as these circumstances passed, doubts about such judicial resolution increased. One of these circumstances was the common assumption that constitutional violations typically would be obvious and scarcely controvertible. Alexander Hamilton's argument in The Federalist, for example, supposed "an irreconcileable variance" between the Constitution and a statute, ${ }^{22}$ the statute being "contrary to the manifest tenor of the constitution ...."23 James Wilson, extolling the judiciary's role as "noble guard," only postulated statutes "manifestly repugnant" to the Constitution. ${ }^{24}$

grounds.

19. See, e.g., Chisholm v. Georgia, 2 U.S. (2 Dall.) 419, 433 (1793).

In his opinion in Chisholm, Justice Iredell articulated the judicial duty with respect to constitutional questions in terms similar to those he had used in a 1786 publication, and as counsel in the North Carolina case of Bayard v. Singleton, 1 N.C. (1 Mart. 48) 5 (1787). That publication and the Bayard argument are documented in SYLVIA SNOWISS, JUDICIAL REVIEW AND THE LAW OF THE CONSTITUTION 45-53 (1990), albeit with commentary I find rather inapt.

20. 1 WORKS OF WILSON, supra note 10 , at 330 (Lecture XI).

21. 5 U.S. (1 Cranch) at 176.

22. The Federalist No. 78, at 525 (Alexander Hamilton) (Jacob E. Cooke ed., 1961).

23. Id. at 524 .

24. 1 WORKS OF WILSON, supra note 10, at 329 (Lecture XI).

The "flip-side" of this assumption is the numerous statements by judges that they would only hold a measure unconstitutional, as Justice Chase said, "in a very clear case," Hylton v. United States, 3 U.S. (3 Dall.) 171, 175 (1796); or as Justice Livingston said at 
Such an assumption must, today, seem rather naive. ${ }^{25}$ It would have seemed less so in those early years, however, before much experience with the difficulty of interpreting and applying written constitutions had been accumulated. ${ }^{26}$ In any event, if many who at the outset thought courts should disregard unconstitutional statutes were so naive as to anticipate only "manifest" conflicts, that fact itself is important: As experience presented issues less clear-cut, the political significance of judicial disapproval

Circuit, "unless the case were so clearly so that it were scarcely possible for any two men to differ in sentiment on the subject," The Elizabeth, 8 F. Cas. 468, 470 (C.C.D.N.Y. 1810) (No. 4352). "If, then, by any fair and reasonable interpretation, where the case is at all doubtful, the law can be reconciled with the constitution, it ought to be done ...." Adams v. Storey, 1 F. Cas. 141, 142 (C.C.D.N.Y. 1817) (No. 66).

Ironically it was Spencer Roane-a Virginia state judge who would emerge as a Jefferson ally bitterly opposed to the Federalist cause-who took a more latitudinous view:

[T] he judiciary may and ought to adjudge a law unconstitutional and void, if it be plainly repugnant to the letter of the Constitution, or the fundamental principles thereof. By fundamental principles I understand, those great principles growing out of the Constitution, by the aid of which, in dubious cases, the Constitution may be explained and preserved inviolate; those land-marks, which it may be necessary to resort to, on account of the inpossibility to foresee or provide for cases within the spirit, but without the letter of the Constitution.

Kamper v. Hawkins, 3 Va. (1 Va. Cas.) 20, 40 (Gen. Ct. 1793). Contrast even that most resolute champion of judicial supremacy, Joseph Story, who wrote, "sound discretion requires, that the court should not lightly presume an excess of power by the legislative body; nor so construe the generality of words, as to extend them beyond its lawful authority, unless the conclusion be unavoidable." United States v. Wonson, 28 F. Cas. 745, 750 (C.C.D. Mass. 1812) (No. 16,750) (Story, J., concurring).

25. Representations such as that of Story in Wonson, supra note 24, certainly must be skeptically received today; but for most of the first decade of the Constitution, before political positions had hardened, such statements could reasonably have seemed candid, and people across the political spectrum seem to have believed themselves adequately assured.

26. That some constitutional points might be less clear-cut began to appear early, when the First Congress considered how, consistently with the Constitution, an executive department head might be removed. Those urging that Congress take a position on that point (in the bill to establish a Department of Foreign Affairs) reasoned that the judges, should they have occasion to consider it, "would feel great relief in having had the question decided by the representatives of the people," 1 ANNALS OF CONG., supra note 12, at 560 (Abraham Baldwin of Georgia), and probably would not overrule the legislative judgment on a point the Constitution on its face left unclear, id. at 486 (John Lawrence of New York). For that reason a legislative pronouncement on the point was urged as both appropriate and helpful, notwithstanding that the judiciary might (in the words of Fisher Ames of Massachusetts) find occasion to "revise our decision." Id. at 477.

But that discussion in the First Congress took place before the emergence of political parties, and it implicated no immediate policy concerns. Events over the next several years, as those critical circumstances changed, however, would make it evident how frequently highly debatable constitutional questions would arise, and how politically sensitive they could be. 
(or approval) would become more apparent, and reliance upon the judiciary therefore more controversial.

A second circumstance contributing to the widespread enthusiasm for judicial determination of constitutional questions in the early years of the Constitution was the peculiar vigor of the concept of trial by jury. Like their forebears in England several generations before, ${ }^{27}$ the colonists in America prized juries as protection against what they considered oppression, and insisted that juries rightfully should be able to decide the law as well as the facts. ${ }^{28}$

Practice continued on this pattern for years after approval of the new federal Constitution, not only in criminal but in civil cases. James Wilson, for example, said in the first of his 1790-1791 Law Lectures: "It is true, that, in matters of law, the jurors are entitled to the assistance of the judges; but it is also true, that, after they receive it, they have the right of judging for themselves . . . ."29 In a later lecture, Wilson elaborated:

[I]t is incumbent on the judges to inform the jury concerning the law; and it is incumbent on the jury to pay much regard to the information, which they receive from the judges. But... [s] uppose that, after all the precautions taken to avoid it, a difference of sentiment takes place between the judges and the jury, with regard to a point of law .... The jury must do their duty, and their whole duty; they must decide the law as well as the fact. $^{30}$

27. See Austin W. Scott, Trial by Jury and the Reform of Civil Procedure, 31 HARV. L. REv. 669, 676 (1918).

28. John Adams, for example, wrote that "the common people should have as complete a control, as decisive a negative, in every judgment of a court of judicature" as they had in the legislature; he considered it an "absurdity" that jurors should be required to accept a judge's view of the law "against their own opinion, judgment, and conscience." 2 THE WORKS OF JOHN ADAMS 253, 254 (Charles F. Adams ed., 1850). He continued: "It is not only [the juror's] right, but his duty, in that case, to find the verdict according to his own best understanding, judgment, and conscience, though in direct opposition to the direction of the court." Id. at 255 .

29. 1 WORKS OF WiLSON, supra note 10 , at 74 (Lecture I).

30. 2 id. at 540 (Lecture VI). This did not mean, of course, that a jury was free to contrive such "law" as it chose:

[]]urors possess the power of determining legal questions. But they must determine those questions, as judges must determine them, according to law. The discretionary powers of jurors find no place for exertion here.... [L]aw, particularly the common law, is governed by precedents, and customs, and authorities, and maxims: those precedents, and customs, and authorities, and maxims are alike obligatory upon jurors as upon judges, in deciding questions of law. 
Pursuant to this practice, in 1794 a claim brought originally in the Supreme Court by the state of Georgia was put to a jury even though the parties agreed on the facts. Instructing the jury, Chief Justice John Jay recited the unanimous opinion of the Court on the relevant treaty and international law questions, and then reminded the jurors of "the good old rule, that on questions of fact, it is the province of the jury, on questions of law, it is the province of the court, to decide." ${ }^{31}$ But, continued the Chief Justice,

it must be observed that ... you have nevertheless a right to take upon yourselves to judge of both, and to determine the law as well as the fact in controversy .... [W]e have no doubt, you will pay that respect, which is due to the opinion of the court. For, as on the one hand, it is presumed, that juries are the best judges of facts; it is, on the other hand, presumable, that the court are the best judges of law. But still both objects are lawfully, within your power of decision. ${ }^{32}$

Not only ideology, ${ }^{33}$ but also practical considerations, reinforced this belief that juries should be able to determine the law. In the first place, the judges of many tribunals were themselves unlearned in law, ${ }^{34}$ making it unsurprising that jury evaluation of

Id. at 542 .

31. Georgia v. Brailsford, 3 U.S. (3 Dall.) 1, 4 (1794).

32. Id. For an elaborate discussion of early American cases and authorities on this point, see Sparf \& Hansen v. United States, 156 U.S. 51, 110-82 (1895) (Gray, J., with Shiras, J., dissenting); see also Bingham v. Cabot, 3 U.S. (3 Dall.) 17 (1795); VanHorne's Lessee v. Dorrance, 2 U.S. (2 Dall.) 304, 28 F. Cas. 1012 (C.C.D. Pa. 1795) (No. 16,857); Lessee of the Proprietary v. Ralston, 1 U.S. (1 Dall.) 18 (Pa. 1773); Anonymous, 1 U.S. (1 Dall.) 20 (Pa. 1773); Boehm v. Engle, 1 U.S. (1 Dall.) 15 (Pa. 1767); Lessee of Albertson v. Robeson, 1 U.S. (1 Dall.) 9 (Pa. 1764).

33. Thomas Jefferson wrote in $\mathbf{1 7 8 9}$ that although jurors generally are not qualified to judge questions of law,

permanent judges acquire an Esprit de corps, ... they are misled by favor, by relationship, by a spirit of party, by a devotion to the Executive or Legislative .... It is left therefore to the juries, if they think the permanent judges are under any bias whatever in any cause, to take on themselves to judge the laws as well as the fact .... [B]y the exercise of this power they have been the firmest bulwarks of English liberty. Were I called upon to decide, whether the people had best be omitted in the Legislative or Judiciary department, I would say it is better to leave them out of the Legislature. The execution of the laws is more important than the making them. However it is best to have the people in all the three departments where that is possible.

Letter from Thomas Jefferson to L'Abbe Arnoux (July 19, 1789), in 15 PAPERS OF JEFFERSON, supra note 11, at 283.

34. James Wilson observed in $\mathbf{1 7 9 0}$ that "in many respectable courts within the United States, the judges are not, and, for a long time, cannot be gentleinen of professional 
legal arguments of counsel should flourish. But second, and more important, the Circuit Courts, the principal federal tribunals under the 1789 Judiciary Act, ${ }^{35}$ and most courts of general jurisdiction in the States, were typically staffed not by one but by several judges. Frequently the two or more judges sitting for a trial would disagree on points of law, and so each would instruct the jury in turn. Moreover, in the early federal system and in that of several States, appellate review was in most cases either precluded or severely encumbered; ${ }^{36}$ trial dispositions usually were conclusive, and thus prior appellate rulings seldom were available for guidance. Hearing two or more judges of equivalent stature give different advice as to the law, and knowing their verdict would be dispositive, a jury could hardly do otherwise than decide the law as well as the facts.

Under these circumstances, there was no reason to expect the jury's role to be less substantial with respect to constitutional than with respect to other legal questions. Indeed, in contrast particularly to arcane niceties of the common law, the Constitution was concisely and plainly written and widely published-convenient reading for any literate juror. Given the public's high regard for trial by jury, this assumption that jurors, no less than judges, would participate in judicial determinations of constitutional ques-

acquirements." 1 WORKS OF WILSON, supra note 10 , at 74 (Lecture I). Wilson urged that such judges "ought to make the strongest efforts in order to obtain a respectable degree of knowledge in the law." Id. at 75.

35. Under the original Judiciary Act of 1789, ch. 20, 1 Stat. 73, the Circuit Court bench was to consist of two itinerant Justices sitting with the District Judge for whichever judicial district the Circuit Court was convened in at the tine. Under an amendment adopted four years later, the attendance of a single Justice. with the District Judge was sufficient. Act of Mar. 2, 1793, ch. 22, § 1, 1 Stat. 333.

36. See generally David E. Engdahl, What's in a Name? The Constitutionality of Multiple 'Supreme' Courts, 66 IND. L.J. 457 (1991) (arguing that the present hierarchical design of our judicial system is not required by the text of the Constitution). 
tions $^{37}$ must have facilitated acceptance of the idea that constitutional provisions should be interpreted in court.

Insofar as constitutional questions might be addressed by judges, either in jury instructions or otherwise, a third circumstance contributed greatly to the early enthusiasm for judicial determination. Although patriots during the late colonial period had criticized some judges for royal bias, Americans adhered to the traditional common law conception of judges, according to which, as Blackstone had expressed it, a judge is "sworn to determine, not according to his own private judgment, but according to the known laws and customs of the land; not delegated to pronounce a new law, but to maintain and expound the old one."38

37. The practice was by no means limited to indulgence of so-called "nullification verdicts" acquitting criminal defendants; it also countenanced convictions a judge might deem unconstitutional. This point is well illustrated by Justice Livingston's jury instruction in a treason trial at Circuit in 1808. After forcefully detailing his own firm opinion (contrary to that of the prosecuting United States District Attorney) that the circumstances of the case could not even remotely satisfy the Constitution's definition of treason, see U.S. CONST. art. III, $\S 3$, Livingston said to the jury, "[t]he whole case, both law and fact, is now committed to you, in the fullest confidence, that you will do justice . . . ." United States v. Hoxie, 26 F. Cas. 397, 403 (C.C.D. Vt. 1808) (No. 15,407). While the jurors were duty-bound, as Livingston said,

to pay a very respectful consideration to every proposition of law you may receive from the court .... a jury has a right to take upon itself the decision of both law and fact. There is no design in the court to dispute this position, or in any degree to encroach on your prerogatives.

Id. at 402. The defendant in that case was acquitted; but both Livingston's express statements, and the effort evident in his charge to persuade rather than to direct, manifest that he would have found a guilty verdict equally lawful, although contrary to the judges' opinions on the law-including on the constitutional point.

The prospect of jury determination of constitutional issues had been raised in the First Congress when John Page of Virginia, referring to unilateral removal of a department head, said that if the President "judges himself to be possessed of the power of removal, he will use it, and submit it to his country to judge whether he was vested with it or not.... [Thus] we shall leave the Constitution to the proper expositors of it . . ." 1 ANNALS OF CONG., supra note 12, at 548, 550 (emphasis added).

38. 1 BLACKSTONE, supra note 8 , at 69 .

As elaborated by Blackstone, this conception of the judges' function had been integral to the conception of the common law itself as being, in its essence, timeless and immemorial unwritten custom. In the sentences immediately preceding the passage quoted in the text, Blackstone wrote that the judges'

knowledge of that law is derived from experience and study; ... and from being long personally accustomed to the judicial decisions of their predecessors. And indeed these judicial decisions are the principal and most authoritative evidence, that can be given, of the existence of such a custom as shall form a part of the common law.... And therefore, even so early as the conquest, we find the "praeteritonum memoria eventonim" reckoned up as one of the chief qualifications of those, who were held to be "legibus patriae optime instituti." For it is an established rule to abide by former precedents, where the 
Thus, discussing judicial determination of constitutional questions, Alexander Hamilton argued that although the judiciary must engage in the "exercise of judicial discretion," 39 it "may truly be said to have neither Force nor Will, but merely judgment . . .."40 Relying on this premise, Madison felt comfortable in 1788 (although he felt differently a decade later ${ }^{41}$ ) trusting the judiciary to enforce the (erroneous) "dual federalism" notion ${ }^{42}$ he (mistakenly) maintained constitutionally restricted the federal government's power. Although "the tribunal which is ultimately to decide, is to be established under the general Government," Madison wrote, "[t]he decision is to be impartially made, according to the rules of

same points come again in litigation; as well to keep the scale of justice even and steady, and not liable to waver with every new judge's opinion; as also because the law in that case being solemnly declared and determined, what before was uncertain, and perhaps indifferent, is now become a permanent rule, which it is not in the breast of any subsequent judge to alter or vary from, according Id.

to his private sentiments....

A little reflection should lead one to doubt the relevance of this traditional conception of judging to the circuinstance of constitutions both new and written down. On the other hand, however, tradition gave the Americans no other model on which to draw.

39. THE FEDERALIST No. 78, supra note 22, at 525 .

40. Id. at 523. Hainilton argued further that

[a] constitution is in fact, and must be, regarded by the judges as a fundamental law. It therefore belongs to them to ascertain its meaning as well as the meaning of any particular act proceeding from the legislative body .... [Therefore, i]t can be of no weight to say, that the courts on the pretence of a repugnancy, may substitute their own pleasure to the constitutional intentions of the legislature. This might as well happen in the case of two contradictory statutes; or it might as well happen in every adjudication upon any single statute. The courts must declare the sense of the law; and if they should be disposed to exercise WILL instead of JUDGMENT, the consequence would equally be the substitution of their pleasure to that of the legislative body. The observation, if it proved any thing, would prove that there ought to be no judges distinct from that body.

Id. at 525-26.

41. See infra text accompanying notes 53-55, 69-70.

42. As Madison expressed it:

[T] he local or municipal authorities form distinct and independent portions of the supremacy, no more subject within their respective spheres to the general authority, than the general authority is subject to them, within its own sphere. In this relation then the proposed Government cannot be deemed a national one; since its jurisdiction extends to certain enumerated objects only, and leaves to the several States a residuary and inviolable sovereignty over all other objects.

THE Federalist No. 39, at 256 (James Madison) (Jacob F. Cooke ed., 1961); see also THE FEDERALIST No. 32 (Alexander Hamilton) (discussing the division of sovereign power and the necessity of concurrent jurisdiction). For a critical discussion of the fundamental errors of the "dual federalism" model, see generally DAVID E. ENGDAHL, CONSTITUTIONAL FEDERALISM IN A NUTSHELL (1987). 
the Constitution; and all the usual and most effectual precautions are taken to secure this impartiality." 1793 reiterated the thesis; he wrote that courts were not "in effect the makers of a new law," but rather "as certainly they alone ought to be expositors of an existing one .... [T] [Te application of law, not the making of it, is the sole province of the Court."

This conception that courts exercise no will, make no law, and exercise judgment merely as "expositors of an existing" law, was not peculiar to English thought. In fact, it was essential to classic separation of powers doctrine: The conception articulated by Hamilton and Iredell and alluded to by Madison was also that which had been held by Montesquieu, who had considered judges mere functionaries, "no more ... than the mouth that pronounces the words of the law, mere passive beings incapable of moderating either its force or rigor." ${ }^{45}$

It was this conception of the judicial function that made it seem possible, at the outset, to reconcile with the premise of republican government the judicial disregard of unconstitutional statutes. That today we regard this conception as quaint is significant: As observers came to perceive elements of will in judicial decisions, the political potential of judicial determinations of con-

43. The Federalist No. 39 , supra note 42 , at 256-57.

44. Chisholm v. Georgia, 2 U.S. (2 Dall.) 419, $448-49$ (1793).

45. 1 Charles-Louis de SECONDAT, BARON DE MONTESQuieu, THE SPIRIT OF LAws 209 (David W. Carrithers ed., 1977) (1748). That is why he could characterize the function of judging, devoid of both initiative and will, as "in some ways nothing" (en quelque façon nulle) compared to the functions of making laws and executing them, so that "there remain . . . only two" that should be called "powers," after all. Id. at 206.

It was precisely because it would compromise this absence of policy and statecraft in the judiciary that Montesquieu concluded "there is no liberty, if the power of judging be not separated from the legislative and executive powers." Id. at 202. As if uncannily anticipating the modern phenomenon of instrumentalist jurisprudence, Montcsquieu wrote, "Were [the judicial] jomed with the legislative, the life and liberty of the subject would be exposed to arbitrary control; for the judge would be then the legislator." Id.

In the same vein, James Wilson said:

Let us suppose the legislative and judicial powers united: what would be the consequence? The lives, liberties, and properties of the citizens would be committed to arbitrary judges, whose decisions would, in effect, be dictated by their own private opinions, and would not be governed by any fixed or known principles of law. For though, as judges, they might be bound to observe those principles; yet, Proteus-like, they might immediately assume the form of legislators; and, in that shape, they might escape from every fetter and obligation of law.

1 WoRKS of WILSON, supra note 10, at 284, 298 (Lecture X). 
stitutionality would become apparent, and confidence in courts for this purpose therefore would wane.

\section{THE CONTROVERSY OVER JUDICIAL SUPREMACY DURING THE LATE 1790s}

By late in the 1790 s, all of these circumstances contributing to the early enthusiasm for judicial resolution of constitutional questions (or, at least, the public perception of these circumstances) had very materially changed. First, heated disputes during that first decade discredited the assumption that the unconstitutionality of statutes typically would be manifest or incontrovertible. ${ }^{45}$ Second, in highly publicized prosecutions under the Sedition Act of $1798,{ }^{47}$ Supreme Court Justices sitting with District Judges at Circuit repelled every attempt to let juries determine whether that widely reproved Act was constitutional ${ }^{48}$ Such abrogation of the familiar practice of juries deciding questions of law ${ }^{49}$-in cases comparable to those memorable seditious libel prosecutions in which courageous jurors had vindicated principles of free speech and publication in the face of directives by English or colonial judges ${ }^{50}$ - seemed to many an attack on liberty itself. And third,

46. E.g., the furor over the ability to sue States, see Chisholm v. Georgia, 2 U.S. (2 Dall.) 419 (1793), that led to the Eleventh Amendment; the controversy over the carriage tax, see Hylton v. United States, 3 U.S. (3 Dall.) 171 (1796); and most notable and enduring of all, the great split between Hamilton and Jefferson over the "necessary and proper" clause, see Opinion on the Constitutionality of an Act to Establish a Bank, in 8 THE PAPERS OF AlEXANDER HAMILTON 97 (Harold C. Syrett ed., 1965); Opinion on the Constitutionality of the Bill for Establishing a National Bank, in 19 PAPERS OF JEFFERSON, supra note 11 , at 275 .

47. Act of July 14, 1798, ch. 74, 1 Stat. 596 (expired Mar. 3, 1801).

48. See United States v. Callender, 25 F. Cas. 239 (C.C.D. Va. 1800) (No. 14,709); Lyon's Case, 15 F. Cas. 1183 (C.C.D. Vt. 1798) (No. 8646); see also GOEBEL, ANTECEDENTS, supra note 7 , at 646.

The argument for jury determination had merit even on the face of the Act: It contamed a clause saying that "the jury who shall try the cause, shall have a right to determine the law and the fact, under the direction of the court, as in other cases." Act of July 14, 1798, $\S 3$; see also 8 ANNALS OF CONG. 2134-37 (1798) (House debate on jury decision of matters of law).

49. Testimony at the impeachment trial of Justice Chase affirmed "that the usual practice in Pennsylvania was for judges to inform the jurors 'what, in the opinion of the court, was the law, but that the jury were the judges of the law and the fact.' " Mark D. Howe, Juries as Judges of Criminal Law, 52 HARV. L. REV. 582, 595 (1939) (footnote omitted).

50. See, e.g., Sparf \& Hansen v. United States, 156 U.S. 51, 110-83 (1895) (Gray, J., with Shiras, J., dissenting); JAMES ALEXANDER, A BRIEF NARRATIVE OF THE CASE AND 
the same Justices and Judges (all of them "Federalists," of course) thus deprecating trial by jury then themselves rejected every argument against the constitutionality of the Sedition Act, ${ }^{{ }_{1}}$ seeming to dodge by casuistic arguments even the straightforward language of the First Amendment. The politically disaffected were thus disabused of any illusion that judges could be trusted to find and apply the law, untainted by predilection and partisan bias.

Faced with these changed circumstances, the leaders of the disaffected reassessed their premises and explored other options. Madison and Jefferson responded to the Sedition Act (and the Alien Act $^{52}$ passed a few days before) by trying to stir state legislatures to respond to Congress's exceeding (in their view) its "necessary and proper" and other powers, as well as its transgressing the First Amendment. Their Kentucky and Virginia Resolutions of November and December, $1798,{ }^{53}$ did not dispute the proposition that courts should decide constitutional questions; both of them still supported that practice. ${ }^{54}$ But neither Jefferson nor Madison

TRIAL OF JOHN PETER ZENGer (1963).

51. Constitutional challenges in court to the Sedition Act had been anticipated even while the measure was pending in Congress. Nathaniel Macon of North Carolina, for example,

was convinced that Congress does not possess the power to pass a law like the present; but if there be a majority determined to pass it, he could only hope that the Judges would exercise the power placed in them of determining the law an unconstitutional law, if, upon scrutiny, they find it to be so. 8 ANNALS OF CONG. 2152 (1798).

The possibility of putting the constitutional question to juries was anticipated during the debate. The jury language ultimately placed in the bill-suggested by Pennsylvania Republican Albert Gallatin-arose out of conflict and compromise. See Howe, supra note 49 , at 586-87. It seems likely that this language was taken to mean different things by different legislators, each accepting it with determination that it should ultimately be rcad his own way.

52. Act of July 6, 1798, ch. 66, 1 Stat. 577 (expired).

53. 1 DOCUMENTS OF AMERICAN History 178, 182 (Henry S. Cominager ed, 6th ed. 1958).

54. Indeed, mainline Jeffersonians continued to reiterate it. For example, Alexander Dallas, described as "the most violent Republican of all lawyers at the Bar, and Jefferson's own United States Attorney for Pennsylvania," 1 WARREN, supra note 17, at 298, argued in an 1805 case:

The constitution is the supreme law of the land, and not only this court, but every court in the union is bound to decide the question of constitutionality.

They are bound to decide an act to be unconstitutional, if the case is clear of doubt .... It must be a case in which the act and the constitution are in plain conflict with each other. If the question be doubtful, the court will presume that the legislature has not exceeded its powers."

United States v. Fisher, 6 U.S. (2 Cranch) 358, 384 (1805). 
had ever agreed with the proposition that courts were uniquely competent, or exclusively entitled, to decide constitutional points. They had considered the independence of the judiciary indispensable, but had never endorsed "judicial supremacy." In their Resolutions Jefferson and Madison urged the States themselves, through their legislatures, to memorialize the constitutional violations and instruct their respective congressional delegations to redress them..$^{55}$

The effect of these Resolutions, however, was to harden convictions among those who were not disaffected that constitutional interpretation properly was a function for the judiciary alone, or that in any event the judges' interpretation was supreme.

It had been easy to move, during the earliest years, from the proposition that courts independently must decide constitutional questions arising in their work to a thesis of judicial supremacy or exclusivity; political ramifications had yet to become evident, and there seemed little reason to think that judges might be affected by partisan bias. Judicial supremacy had been endorsed even in the First Congress. Elbridge Gerry of Massachusetts, for example, had said of a constitutional issue being debated: "[L]et it go before the proper tribunal; the judges are the Constitutional umpires on such questions ..... Sir, we are not the expositors of the Constitution .... [T] The judges are the expositors of the constitution and the acts of Congress." ${ }^{956}$ Other Congressmen had expressed similar views..$^{57}$

At that time, only Madison had spoken out to the contrary. He said:

I suppose an exposition of the Constitution may come with as much propriety from the Legislature, as any other department of the Government. ${ }^{s 8}$

55. 1 DOCUMENTS OF AMERICAN HISTORY, supra note 53, at 178, 182.

56. 1 ANNALS OF CONG., supra note 12 at $473,573$.

57. For example, Alexander White of Virginia stated, "I would rather the Judiciary should decide the point, because it is more properly within their department." Id. at 466. William Smith of South Carolina urged that a judgment by Congress on a constitutional question would improperly interfere with the judiciary: "I never can admit it to be right in our Legislative capacity to influence the judges, and throw our weight into either scale to warp their decision .... [I]f it were a matter of doubt, we ought by no means to interfere in adjusting or determining it." Id. at 509-10.

58. Id. at 461 . 
... I acknowledge, in the ordinary course of Government, that the exposition of the laws and Constitution devolves upon the Judiciary. But I beg to know, upon what principle it can be contended, that any one department draws from the constitution greater powers than another, in marking out the limits of the powers of the several departments?... I do not see that any one of these independent departments has more right than another to declare their sentiments on that point. ${ }^{59}$

Nothing has yet been offered to invalidate the doctrine, that the meaning of the Constitution may as well be ascertained by the legislative as by the judicial authority. ${ }^{60}$

Virginia judge St. George Tucker had declared in 1793, with respect to his state's constitution, that "the duty of expounding must be exclusively vested in the judiciary." That might have reflected a peculiarity in Virginia's state constitution; ${ }^{62}$ otherwise,

59. Id. at 500. Madison continued:

There is not one Government on the face of the earth, so far as I recollect, there is not one in the United States, in which provision is made for a particular authority to determine the limits of the Constitutional division of power between the branches of the Government. In all systems there are points which must be adjusted by the departments themselves, to which no one of them is competent. If it cannot be determined in this way, there is no recourse left but the will of the community, to be collected in some mode to be provided by the Constitution, or one dictated by the necessity of the case.

Id. at 500-01.

60. Id. at $546-47$.

61. Kamper v. Hawkins, 3 Va. (1 Va. Cas.) 20, 79 (Gen. Ct. 1793).

62. Although Tucker joined Jefferson in criticizing it for violating this mandate, Virginia's constitution in fact declared that, "[t]he legislative, executive, and judiciary department, shall be separate and distinct, so that neither exercise the powers properly belonging to the other . . . 10 WILLIAM F. SWINDLER, SOURCES AND DOCUMENTS OF UNITED STATES CONSTITUTIONS 51, 52 (1979); 7 THORPE, supra note 7, at 3815.

Reasoning froin this provision, Tucker said that a state constitution becomes the first law of the land, and as such must be resorted to on every occasion, where it becomes necessary to expound what the law is. This exposition it is the duty and office of the judiciary to make; our constitution expressly declaring that the legislative, executive, and judiciary, shall be separate and distinct, so that neither exercise the powers properly belong[ing] to the other. Now since it is the province of the legislature to make, and of the executive to enforce obedience to the laws, the duty of expounding must be exclusively vested in the judiciary.

Kamper, 3 Va. (1 Va. Cas.) at 78-79. Moreover, because under Virginia's scheme, decisions of the Virginia General Court were reviewable by the Court of Appeals, Tucker could add that

the decisions of the supreme court of appeals in this commonwealth, upon any question, whether arising upon the general principles of law, the operation or construction of any statute or act of assembly, or of the constitution of this commonwealth, are to be resorted to by all other courts, as expounding, in 
the developments of that decade moving Tucker into the Jeffersonian camp later led him to alter his view significantly: By 1803 Tucker continued to describe "judicial exposition" as "the bulwark provided against undue extension of the legislative power," did not repeat his earlier claim of judicial exclusivity. ${ }^{64}$

their truest sense, the laws of the land; and where any decision of that court applies to a case depending before any other tribunal, that tribunal is bound to regulate its decisions conformably to those of the court of appeals.

Id. at 93 .

63. St. George Tucker, Appendix to 1 BLACKSTONE, supra note 8, at app. 288. "Thus, if the legislature should pass a law dangerous to the liberties of the people, the judiciary are bound to pronounce... . whether such a law be permitted by the constitution." Id. at 357.

The obligation which the constitution imposes upon the judiciary department to support the constitution of the United States, would be nugatory, if it were dependent upon either of the other branches of the government, or in any manner subject to their control, since such control might operate to the destruction, instead of the support, of the constitution. Nor can it escape observation, that to require such an oath on the part of the judges, on the one hand, and yet suppose them bound by acts of the legislature, which may violate the constitution which they have sworn to support, carries with it such a degree of impiety, as well as absurdity, as no man who pays any regard to the obligations of an oath can be supposed either to contend for, or to defend. Id. at 355 .

64. State judges could read the Federal Constitution as well as (or better than) federal judges could, so if "the federal government should exercise powers not warranted by the constitution,... . where the act of usurpation may immediately affect an individual, the remedy is to be sought by recourse to that judiciary, to which the cognizance of the case properly belongs." Id. at app. 153 (emphasis added). For any particular case, the judiciary "to which the cognizance . . . belongs" might be the federal, but more often (at that time) would be some state judiciary-at least in the first instance, and perhaps even in the last: In Martin v. Hunter's Lessee, 14 U.S. (1 Wheat.) 304, 315-16 (1816), an advocate referred to only as "Tucker" denied that federal courts could review or revise state court decisions of federal questions; and Charles Warren identified this advocate as St. George Tucker himself. See 1 WARREN, supra note 17, at 448 . But Warren might have been mistaken: St. George Tucker, then alınost 64, was at that time the District Judge for Virginia. See 30 F. Cas. 1399. Thus, it seems likely the "Tucker" referred to in Wheaton's Report was his son, Henry St. George Tucker. Henry was counsel for the same interests at an earlier stage of the saine litigation, when it was before the Virginia Court of Appeals on which his father then sat (a circumstance which had led the older man to recuse himself, see Hunter v. Fairfax's Devisee, 15 Va. (1 Munf.) 218, 223 (1810), rev'd sub nom. Fairfax's Devisee v. Hunter's Lessee, 11 U.S. (7 Cranch) 603 (1812)).

Where the "act of usurpation" did not "immediately affect an individual," but did affect a state, the remedy Tucker called for was not judicial, but rather resembled that attempted by the Virginia and Kentucky Resolutions:

Where it may affect a state, the state legislature, whose rights will be invaded by every such act, will be ready to mark the innovation and sound the alarm to the people: and thereby either effect a change in the federal representation, or procure in the mode prescribed by the constitution, further "declaratory and restrictive clauses", by way of amendment thereto.

Tucker, supra note 63, at app. 153. 
By 1798, constitutional propositions had become points of partisan debate; and as no federal judge had been appointed from among the politically disaffected, judicial supremacy could no longer be an uncontroversial idea. It had become, for the most part, a doctrine of the Federalist establishment; and it became more imperative to the Federalists as Jacobin and States' rights specters loomed. ${ }^{65}$

That is why Federalist-dominated legislatures responded to the Virginia and Kentucky Resolutions with such adamant assertions of the judicial supremacy view. Rhode Island's legislature declared that the Constitution "vests in the Federal Courts, exclusively, and in the Supreme Court of the United States, ultimately, the authority of deciding on the constitutionality of any act or law of the Congress of the United States." resolved that the task of determining the constitutionality of federal laws "is properly and exclusively confided to the judicial department." 67

Madison's rejoinder to these Federalist assertions of judicial supremacy emphasized a point he had made earlier at the Constitutional Convention. The point had arisen when jurisdictional parameters for the national judiciary were discussed:

Docr. Johnson moved to insert the words "this Constitution and the" before the word "laws"

Mr Madison doubted whether it was not going too far to extend the jurisdiction of the Court generally to cases arising Under the Constitution, \& whether it ought not to be limited to cases of a Judiciary Nature. The right of expounding the Constitution in cases not of this nature ought not to be given to that Department.

The motion of Docr. Johnson was agreed to nem: con: it being generally supposed that the jurisdiction given was constructively limited to cases of a Judiciary nature- ${ }^{63}$

In his 1800 Report on responses to the Virginia Resolutions, Madison admitted that federal courts have exclusive or "last resort" cognizance in some instances, ${ }^{69}$ but carefully qualified this conces-

65. See 1 WARREN, slupra note 17 , at 187 n.1.

66. 1 DOCUMENTS OF AMERICAN HISTORY, supra note 53, at 184.

67. Id. at 185; see also, e.g., MASSACHUSETTS RESOLUTIONS IN REPLY TO VIRGINIA, reprinted in JEFFERSON POWELL, LANGUAGES OF POWER 135 (1991).

68. 2 RECORDS, supra note 9 , at 430.

69. The Report was approved by Virginia's General Assembly to answer state re- 
sion: He agreed only that, as among federal departments, "the Judicial Department, is, in all questions submitted to it by the forms of the constitution, to decide in the last resort...."70 Madison's point was still the same as it had been at the Constitutional Convention and in the First Congress: What makes the judiciary the appropriate decider of a question, and sometimes makes it the last recourse among federal departments on a constitutional (as on any other legal) question, is not the character of the question, but rather the accident of its occurrence in a form contemplated by Article III.

On this, as on most but not all other matters, Jefferson and Madison were aligned. During the 1790 s, these Virginia intimates had together built a reasonably disciplined party of those disaffected by Federalist policies. Their jointly strategized Resolutions effort was only one fruit of the countless conversations about political matters they shared at Monticello, at Montpelier, when travelling together, and when both were resident at the capital. It might well have been Madison's persistence on this point that led Jefferson to the position he formulated ${ }^{71}$ for his address at the opening of the Seventh Congress on December 8, 1801:

[O]ur country has thought proper to distribute the powers of it's government among three equal \& independent authorities, constituting each a check on one or both of the others, in all attempts to impair it's constitution. [T] make each an effectual check, it must have a right in cases which arise within the line of it's

sponses to Virginia's 1798 Resolution. 17 PAPERS OF MADISON, supra note 11, at 307, 311.

Madison conceded for the sake of argument that judicial supremacy might make sense within any state's .own separate polity, but insisted it would be anomalous in construing, as between the "sovereigns," a "compact to which the states are parties." See id. at $308-10$.

70. Id. at 311 (emphasis added).

71. There has been argument over whether Jefferson's view was consistent over time. See, e.g., Samuel Krislov, The Alleged Inconsistency: A Revised Version, 10 J. PUB. L. 117 (1961); Wallace Mendelson, Jefferson on Judicial Review: A Reply to Professor Krislov, 10 J. PUB. L. 113, 114-15, 117 (1961); Mendelson, supra note 3, at 332. If it is true that his view in 1801 and afterwards was different from that he had held before, circumstances indicated earlier in the text are ample to indicate why.

Jefferson did not himself endorse "legislative supremacy," but some of his political allies did; and later in life he expressed his sufferance of that view. See Letter from Thomas Jefferson to W.H. Torrance (June 11, 1815) [hereinafter Letter from Jefferson to Torrance], in 14 THE WRITINGS OF THOMAS JEFFERSON 302, 305-06 (Albert Ellery Bergh ed., 1904) [hereinafter WRITINGS OF JEFFERSON]. 
proper functions, where, equally with the others, it acts in the last resort \& without appeal, to decide on the validity of an act according to it's own judgment, \& uncontrouled by the opinions of any other department. [W] have accordingly, in more than one instance, seen the opinions of different departments in opposition to each other, \& no ill ensue. ${ }^{n}$

Jefferson repeated the point some years later:

The constitution intended that the three great branches of the government should be co-ordinate, and independent of each other. As to acts, therefore, which are to be done by either, it has given no control to another branch .... Where different branches have to act in their respective lines, finally and without appeal, under any law, they may give to it different and opposite constructions.... From these different constrnctions of the same act by different branches, less mischief arises than from giving to any one of them a control over the others. ${ }^{73}$

\section{JOHN MARSHALL'S CONCEPT IN 1800}

A year before Jefferson's inauguration as President, John Marshall as a member of the Sixth Congress prominently articulated the same view expressed earlier by Madison and endorsed

72. 3 AlberT J. BeVERIDGE, THE LIFE of JoHn MARSHall 605 (1919). Jefferson excised the passage from which these sentences are taken before the message was delivered, noting in the margin that he deleted the passage as "capable of being chicaned, and furnishing something to the opposition to make a handle of" and because he preferred the message to be "clear of everything which the public might be made to misunderstand." $3 \mathrm{id}$. at 52-53.

73. Letter from Thomas Jefferson to George Hay (June 2, 1807), in 11 WRITINGS OF JEFFERSON, supra note 71, at 213-14 [hereinafter Letter from Jefferson to Hay]; see also Letter from Thomas Jefferson to Abigail Adams (Sept. 11, 1804), in 11 WRITINGS of JEFFERSON, supra note 71, at 51; Letter from Jefferson to Torrance, supra note 71, at 303-04.

In 1820 Jefferson again wrote that regarding judges as "the ultimate arbiters of all constitutional questions" was

a very dangerous doctrine indeed, and one which would place us under the despotism of an oligarchy .... The Constitution has erected no such single tribunal, knowing that to whatever hands confided, with the corruptions of time and party, its members would become despots. It has unore wisely made all the departments co-equal and co-sovereign within themselves ..... [T] he Constitution, in keeping three departments distinct and independent, restrains the authority of the judges to judiciary organs, as it does the executive and legislative to executive and legislative organs.

Letter from Thomas Jefferson to William L. Jarvis (Sept. 28, 1820), in 15 WritiNGS OF JEFFERSON, supra note 71 , at $277-78$. 
later by Jefferson as indicated above. The occasion was his powerful speech against Republican House resolutions to censure President John Adams. The situation Marshall addressed was complex; for the import of his argument to be correctly understood, a good deal of background is required.

There had been a bloody mutiny on September 22, 1797, aboard the British frigate Hermione. ${ }^{74}$ Afterwards, Britain sought to apply its military justice to the mutineers as they severally were found.

When the first of them to appear in America showed up in Delaware in February 1798, Britain's Minister Robert Liston requested of Secretary of State Timothy Pickering that "the American Government will without delay give the necessary orders that he be apprehended and kept in secure custody till an opportunity occur of sending him home for trial." 75 However, the Jay Treaty (ratified in 1795) required extradition only on such evidence as would be sufficient under American law to justify commitment for trial had the offense charged been committed here. ${ }^{76}$ Liston could show nothing more inculpatory than that the alleged mutineer had been aboard the Hermione. Within two days, Pickering conferred with President Adams, who declined to extradite the alleged mutineer because evidence sufficient under the Jay Treaty had not been shown. ${ }^{\pi}$

Less than a month later, three more Hermione sailors were found, this time in New Jersey. With regard to the sailor found in Delaware, the highest diplomatic channels had alone been used;

74. The nearly definitive account of affairs in American courts and in Congress in the wake of the Hermione mutiny, and of the complicated legal issues involved, is Professor Ruth Wedgwood's monumental article. See Ruth Wedgwood, The Revolutionary Martyrdom of Jonathan Robbins, 100 YALE L.J. 229 (1990). While in some particulars I disagree with her inferences, suspicions, and tone, I hold Professor Wedgwood's masterpiece in the highest regard.

Responding to a copy of the manuscript for this article, Professor William A. Fletcher of Boalt Hall shared with me his own draft manuscript on the Nash (Robbins) affair, written before Professor Wedgwood's work was published. Professor Fletcher's excellent study, when published, will merit the reader's attention.

75. Wedgwood, supra note 74 , at 270.

76. Treaty of Amity Commerce and Navigation, Nov. 19, 1794, U.S.-G. Brit., art. XXVII, reprinted in 1 WILLIAM M. MALLOY, TREATIES, CONVENTIONS, INTERNATIONAL ACTS, PROTOCOLS AND AGREEMENTS BETWEEN THE UNTTED STATES AND OTHER POWERS, 1776-1909, at 590, 605 (1910).

77. Five weeks later, Liston pressed his request again, but to no avail. Wedgwood, supra note 74 , at 270 . 
but with regard to those sailors found in New Jersey, federal court records show an order ${ }^{78}$ committing the three "for suspicion of felony" in "inurdering on the high seas," and for "piratically delivering up" the Hermione to Britain's enerny, Spain."

That placed the matter in the American judicial branch, whereas the British wished their own justice to apply. At the instance of Liston, Pickering suggested to Attorney General Charles Lee that, by virtue of the Jay Treaty, if the evidence were sufficient to bind the defendants for trial they would have to be turned over to the British. But Lee elected to let the American judicial process run its course. A month after their arrest, all three were indicted by a grand jury for piracy-and one of them, Brigstock, for murder as well. ${ }^{80}$ The piracy trial took place three days later, ${ }^{81}$ and all three were acquitted, ${ }^{22}$ Brigstock (an American) remained in custody under the murder indictment until later released upon nolle prosequi. ${ }^{83}$

That disagreement between the Secretary of State and the Attorney General as to how diplomatic and judicial processes should interact ${ }^{84}$ presaged what was to come. Another Hermione sailor showed up six inonths after Brigstock's release; this one's treatment precipitated a similar disagreement, but across party lines, and thus ignited a political conflagration.

78. The order was not by any federal official, but by the town recorder and alderman. At the time, state magistrates could and routinely did apprehend and hold persons for trial in federal courts. Judiciary Act of 1789, ch. 20, $\S 33,1$ Stat. 73, 91.

79. The order of commitment was based on two provisions of the Jay Treaty: its extradition article and its promise to punish piracy. Wedgwood, supra note 74, at 271 .

80. Id. at 275 .

81. The trial was before Justice Chase and District Judge Morris, and proceeded despite Secretary of State Pickering's letter to Judge Morris ten days previously requesting that the defendants instead be detained pending President Adams's disposition of Britain's requisition for them. Id. at 276 .

82. Id. at 277.

83. The nolle prosequi on Brigstock's murder charge was entered about six weeks later, the District Attorney reciting that he did so obediently to presidential command. Secretary of State Pickering had asked the District Attorney to relieve the defendant on the basis of an exculpatory letter from Vice Admiral Sir Hyde Parker, British naval commander in the West Indies. Id. at 278. We do not know whether this process was ingenuous, or was a diplomatic maneuver to prevent the United States from being on record officially as refusing extradition (as Professor Wedgwood suggests, id. at 279).

84. Less than ten days after the New Jersey verdict, Pickering wrote to yet another federal District Judge requesting that he detain "seven or eight" other Hermione sailors taken into custody in New York; apparently the detention was to be for purposes of extradition. Id. at 278 . 
Thomas Nash (alias Jonathan Robbins) apparently was placed in jail soon after he arrived in Charleston on February 1, 1799. With Nash (Robbins), the high-level diplomacy that had been tried in Delaware was not employed; but neither, it seems, was Nash detained on criminal charges, as Brigstock and the others had been in New Jersey. Instead, Nash apparently was jailed on the simple request of the British Consul at Charleston, Benjamin Moodie, without any charges at all. ${ }^{85}$ There is no entry in federal court minute books concerning Nash's arrest, ${ }^{86}$ and by the time the May Term of the Circuit Court arrived, although Nash had been in jail three months already, no indictment had even been sought against him. ${ }^{87}$

If Nash was, in fact, detained solely at the Consul's request, his detention (whether "legal" or not) would seem to be strictly a diplomatic, not a judicial, concern, unless and until Nash might seek judicial process to secure his release: for if it had commenced without colorable judicial process, the detention of Nash (but for having been made by Consul rather than Minister, and apparently to some local official rather than to the Secretary of State) was just like that of the first Hermione sailor found in Delaware. This is the view John Marshall would take (although he also would

85. This is consistent with the letter of Minister Liston to Secretary of State Pickering in May, 1799, that Nash had "been committed to jail . . a the instance of His Majesty's Consul [Benjamin Moodie]" at Charleston. Letter from Robert Liston to Timothy Pickering (May 23, 1799), in 10 ANNALS OF CONG. 516 (1800) [hereinafter Letter from Liston to Pickering]. It also is consistent with a November reference by Moodie himself to the "many obstacles I had to encounter in obtaining the delivery of Thomas Nash." Letter from Benjamin Moodie to Robert Liston (Nov. 19, 1799), in 10 ANNALS OF CONG. at 517.

The affidavit of an erstwhile shipmate, Portlock, associated "Robbins" with the Hermione, Wedgwood, supra note 74 , at $286-87$, but we have no proof of by whom or under what claim of authority he was detained.

86. See Wedgwood, supra note 74, at 287 n.225.

Under the Judiciary Act, state magistrates could apprehend and hold persons for trial in federal courts, see supra note 78; but if that were the fact, still it should appear in the federal court record (as it did in the New Jersey case).

It is conceivable, although farfetched, that Nash (Robbins) was held on state charges. Such extant state records as might show whether this were the fact seem not to have been inspected.

87. Only the Circuit, not the District Courts, could take jurisdiction of crimes so grave as murder or piracy; but there is no indication in the Circuit Court Minutes Book, or in the grand jury charge of Chief Justice Ellsworth for the May 1799 term (May 7-15), that any indictment of Nash (Robbins) was sought-for murder or for piracy or for anything else. Wedgwood, supra note 74, at 287. 
argue hypothetically on the possibility of Nash's having been held on charges for trial).

Two months or more after Nash was detained, ${ }^{88}$ Consul Moodie made some sort of "application" 89 for Nash's delivery into British hands. At that time, the federal District Attorney and District Judge Thomas Bee "were of opinion that he could not with propriety be delivered up, without a previous requisition ... made to the Executive Government of the United States." mal diplomatic process therefore ensued, ${ }^{91}$ and on June 3 the Secretary of State wrote to Judge Bee that "[t]he President has ... authorized me to communicate to you 'his advice and request' that Thomas Nash, may be delivered up to the Consul or other agent of Great Britain, who shall appear to receive him." ${ }^{\text {"2 }}$ In response, Judge Bee issued a writ of habeas corpus. ${ }^{93}$

88. While Nash languished in jail, apparently Consul Moodie had sent word of his capture to Britain's naval commander in the West Indies, who sent by cutter a Lieutenant John Forbes. The latter, on April 18,1799, swore an affidavit against Nash to add to that sworn earlier by Portlock. See also Letter from Liston to Pickering, supra note 85.

89. It might have been merely an informal request made of the District Attorney and District Judge in South Carolina; or it might have been the "motion" that the report in United States v. Robins, 27 F. Cas. 825, 827 (D.C.S.C. 1799) (No. 16,175) indicates was ultimately disposed of on July 25 , along with the habeas corpus discussed infra. One should not expect of eighteenth-century practice the same degree of rigor in procedural forms that is expected today.

90. Letter from Liston to Pickering, supra note 85; see also Wedgwood, supra note 74, at 288 n.230. Judge Bee himself later observed: "When application was first made, I thought this a matter for the executive interference, because [to consider an analogy] the act of congress respecting fugitives from justice, from one state to another, refers it alto. gether to the executive of the states . . ." $27 \mathrm{~F}$. Cas. at 833 .

91. Moodie contacted Liston, who approached Pickering, who wrote to President Adams on May 15. Among other things, Pickering reminded Adams of the New Jersey Brigstock case. It therefore is plain that Pickering and Adams both were aware of the contrast between what Lee had done with Brigstock in the administration's name, and what Pickering proposed be done with Nash. Adams replied to Pickering on May 21, two days before Liston formally repeated his request by letter to Pickering. All this is recounted by Wedgwood, supra note 74, at 288-90; some of the correspondence was produced at House request, and is printed at 10 ANNALS OF CONG. 515-17 (1800).

92. Letter from Timothy Pickering to Thomas Bee (June 3, 1799), reprinted in 10 ANNALS OF CONG. 516.

93. On July 1, 1799, Judge Bee wrote to Pickering that: "In compliance with the request of the President ... I gave notice to the British Consul that at the sitting of the district court on this day I should order Thomas Nash . . . to be brought before me on habeas corpus, in order to his being delivered over agreeably" to the Jay Treaty, provid. ed (as the Treaty terms specified) there be proof that would be sufficient to commit one for trial were the offence one committed here. Letter from Thomas Bee to Timothy Pickering (July 1, 1799), reprinted in 10 ANNALS OF CONG. 516-17. 
When the return on that writ at last was heard on July 25,94 Nash (alias Robbins) for the first time went beyond using his alias and claimed that he was an American born in Connecticut who had been pressed into British service, and that he had participated in the "mutiny" and "murder" only to make good his escape. Unpersuaded of this, but satisfied that the evidence was sufficient to oblige delivery under the Treaty, Judge Bee ordered Nash's delivery to the British. Within little more than three weeks, Nash was taken to Jamaica, court martialed, and hanged. ${ }^{95}$

Although earlier he had considered an executive decision to be necessary, by the end of Nash's hearing Judge Bee had changed his mind..$^{96}$ Bee's decision to turn Nash over to the British, therefore, was expressly his own. Moreover, Nash's pseudonym and his claim of Connecticut birth quite certainly were false. ${ }^{97}$ Nonetheless, popular Anglophobia, resentment of the British practice of pressing, and the specter of Americans being delivered over to be hanged without even a jury trial, combined with inaccurate and incomplete information to make this Irish sailor and American pretender a legend among Republican partisans after his death. As a result, resolutions were introduced in the House to censure President Adams for "a dangerous interference of the Executive with Judicial decisions . . . ."

No factual inquiry was made on that date, however; Judge Bee instead granted a requested delay. Bee's letter to Pickering explained: "The Consul attended in court and requested that the prisoner should remain in jail until he had a convenient opportunity of sending him away. I have therefore directed that he remain in prison, until the Consul shall find it convenient to remove him." Id.

94. After the delay granted July 1 on the Consul's request, the case was called again on July 23, by which time the British sloop Sprightly lay at anchor in Charleston harbor waiting to take Nash away. This time Nash was represented by counsel-whom, however, he had engaged just a few minutes before the hearing. Judge Bee therefore adjourned until July 25, at which time different counsel appeared for Nash instead. See Wedgwood, supra note 74 , at $294-301$.

95. Id. at 304.

96. Bee had concluded that:

as the law and the treaty are silent upon the subject [of what process should be pursued], recurrence must be had to the general powers vested in the judiciary by law and the constitution, the $3 \mathrm{~d}$ article of which declares the judicial power shall extend to treaties, by express words.

United States v. Robins, 27 F. Cas. 825, 833 (D.C.S.C. 1799) (No. 16,175).

97. Wedgwood, supra note 74 , at 310-11.

98. Continuing, they declared Judge Bee's "compliance" with Adams's "advice and request" to be "a sacrifice of the Constitutional independence of the Judicial power" which "exposes the administration thereof to suspicion and reproach." The resolutions as proposed are printed at 10 ANNALS OF CONG. 533 (1800). 
His "advice and request" transmitted by Pickering (and, in the end, deemed immaterial by Judge Bee) was not the whole of Adams's "dangerous interference," according to the censure resolutions. To arrive at his conclusion that Nash's circumstances were within the Jay Treaty's terms, Adams must have answered several "questions arising under the Constitution, laws, and treaties, of the United States," which the censure resolutions listed as:

whether the alleged crime of piracy and murder was committed within the exclusive jurisdiction of Great Britain; whether it comes within the purview of [the Jay Treaty extradition provision]; and whether a person stating that he was an American citizen, and had committed the act of which he was accused in attempting to regain his liberty from illegal imprisonment, ought to be delivered up, without any investigation of his claims to citizenship, or inquiry into the facts alleged in his defence . . . .

The resolutions maintained that the very "decision of those questions by the President" was itself a "dangerous interference," for the reason that those questions "are all matters exclusively of judicial inquiry . . ..."1100

Rising to Adams's defense, then-Congressman John Marshall acknowledged that these were indeed profound legal questions under the federal Constitution, laws, and treaties. But contrary to the censure resolutions' reservation of such questions exclusively to the courts, Marshall maintained that in this instance they were questions "the power to decide which rests alone with the Executive department." 101 That was true in this instance, said Marshall, because judicial power under the Constitution does not extend generally to constitutional and other legal "questions," but only to "cases." Marshall explained that

[a] case in law or equity was a term well understood, and of limited signification. It was a controversy between parties which had taken a shape for judicial decision .... To come within this description, a question must assume a legal form for forensic litigation and judicial decision. There must be parties to come into court, who can be reached by its process, and bound by its power; whose rights admit of ultimate decision by a tribunal to which they are bound to submit.

99. Id.

100. Id.

101. Id. at 615 . 
$\ldots$

... A variety of legal questions must present themselves in the performance of every part of Executive duty, but these questions are not therefore to be decided in court. ${ }^{102}$

Stressing precisely the same point Madison had repeatedly made, Marshall stated that the legal questions regarding Nash were for the executive and not the judicial branch because the occasion $^{103}$ "was in its nature a national demand made upon the nation. The parties were the two nations. They cannot come into court to litigate their claims, nor can a court decide on them. Of consequence, the demand is not a case for judicial cognizance." "104

Arguing hypothetically to the Republican thesis that Nash had been in custody for purposes of trial, rather than solely on a diplomatic request for delivery to the British, Marshall referred expressly to the Brigstock case and equated Adams's alleged "interference" regarding Nash to entering a nolle prosequi ${ }^{105}$ Consequently, even disregarding the fact that (as we know from his opinion) Judge Bee, deeming the President's advice immaterial, had made up his own mind, Marshall reasoned that the judicial prerogative to decide independently the same legal ques-

102. Id. at 606,612 . Marshall's biographer, Albert Beveridge, lauded this "great address" as "the highest of Marshall's efforts as a public speaker .... . It is a landmark in Marshall's career and a monument in the development of the law of the land." 2 BEVERIDGE, supra note 72 , at 464 . But his mistaken attribution to Marshall of the doctrine of judicial supremacy demonstrates that Beveridge utterly failed to understand what Marshall had said.

103. The account of Marshall's speech set out in 10 ANNALS OF CONG. 613 (1800), uses here the word "case," not "occasion." But in this instance (as again six paragraphs later, see id. at 614) Marshall plainly was using the word "case" in the loose manner of ordinary speech, and not in the more precise manner he elsewhere used it to distinguish between law "cases" and law "questions."

104. Id. at 613.

Marshall affirmed that the executive must not influence judicial discretion in pending litigation, saying, "[a] private suit instituted by an individual ... can only be controlled by that individual. The Executive can give no direction concerning it." Id. at 609 . Thus, he said, "[h]ad the President directed the Judge at Charleston to decide for or against his own jurisdiction, to condemn or acquit the prisoner, this would have been a dangerous interference with judicial decisions, and ought to have been resisted." Id. at 615-16. But in the Nash case, as he pointed out, "no such direction has been given, nor any such decision been required." Id. at 616.

105. Id. at 615. As he observed, "a public prosecution carried on in the name of the United States can, without impropriety, be dismissed at the will of the Government." Id. at 609. That, of course, is what had been done in the case of Brigstock. See supra note 83. 
tions-even those which might bear upon jurisdiction-remained intact: "Should another prosecution of the same sort be commenced, which should not be suspended but continued by the Executive, the case [that is, incident ${ }^{105}$ ] of Thomas Nash would not bind as a precedent against the jurisdiction of the court."107

Consequently, should the President on some future occasion pursue the advice of Attorney General Lee rather than of Secretary of State Pickering, declining to deliver some other alleged Hermione mutineer and instead pursuing domestic prosecution, the positions taken by President Adams in Nash's case on the identical legal questions would have no bearing at all. Such a prosecution would be a "case" in the "well understood" technical sense of a "case in law or equity"; and for purposes of any "case," the judiciary must independently decide all questions of law-regardless of whether, how, how often, or how consistently the executive might have decided the identical questions in the course of conducting his branch's affairs.

Congressman Marshall certainly knew that the "finality" of a judicial determination in any "case"-the immutability by political branches of an adjudicated outcome-is an indispensable characteristic of "judicial power." $108 \mathrm{He}$ understood, in other words, the

106. See supra note 103.

107. 10 ANNALS OF CONG. 616 (1800).

108. This traditional proposition is the basis on which the federal Judges and Justices had disregarded the 1792 Pension Act, discussed in note 18 supra. Under that Act, Circuit Courts were to determine eligibility and certify claimants to the Secretary of War who, notwithstanding the court's opinion, could withhold a claimant's name from the pension list if he suspected imposition or mistake, and call for an ultimate decision by Congress. In Hayburn's Case, Chief Justice Jay, Justice Cushing, and Judge Duane held that Congress could not assign the judiciary "any duties, but such as are properly judicial," and that because of the provision for executive and legislative revision, "the business assigned to this court, by the [Pension] act, is not judicial . . ." 2 U.S. (2 Dall.) 408, 410 n. $\dagger$ (1792). Justices Blair and Wilson, with Judge Peters, wrote that the revisory power over the courts' determinations was "radically inconsistent with the independence of that judicial power which is vested in the courts; and, consequently, with that important principle ... [that] 'the judicial should be distinct from, and independent of, the legislative department." "Id. at 411-12.

Justice Iredell and Judge Sitgreaves wrote that

inasmuch as the decision of the court is not made final, . . this subjects the decision of the court to a mode of revision, which we consider to be unwarranted by the Constitution .... [N]o decision of any court of the United States can, under any circumstances, in our opinion, agreeable to the Constitution, be liable to a reversion, or even suspension, by the Legislature itself .... Id. at 413 . 
principle of res judicata, and thus knew that any judicial order premised on judicial decision of legal questions must be obeyed by parties and their privies for purposes of the matters litigated regardless of how erroneous anyone might think the premises to be. Thus, given the rest of what Marshall had said, there was great portent to his observation that

if the President should cause to be arrested under the treaty an individual who was so circumstanced as not to be properly the object of such an arrest, he [the individual] may perhaps bring the question of the legality of his arrest before a judge, by a writ of habeas corpus. ${ }^{109}$

By virtue of an individual's doing so, there would be a "case" within the judicial power under Article III, necessarily invoking both the "independence" and the "finality" of judicial disposition in that "case." If in any such "case," the court should order released a prisoner who in the Executive's own view was being lawfully held, the executive would have no choice but to let the prisoner go! $!^{110}$ As the final disposition of the particular case, the judicial order would have to be obeyed, regardless of how erroneous it might be! But that detracts nothing, as Marshall explained, from the Executive's duty independently to decide precisely the

The opinion of the Circuit Court for New York and the letters from the others are printed in a footnote to Hayburn's Case, 2 U.S. (2 Dall.) 408 (1792). See generally 1 WARREN, supra note 17, at 70-71; Ritz, supra note 18, at 223-24 (explaining the reasoning of the circuit courts in refusing to follow the procedures of the Act in their capacity as judicial officials).

Modern students know this point better from discussions of United States v. Klein, 80 U.S. (13 Wall.) 128 (1872), and Gordon v. United States, 69 U.S. (2 Wall.) 561 (1865).

109. 10 Annals of Cong. 615 (1800).

110. It is quite a different thing for a president to pardon a convicted person on what seein to that president persuasive constitutional grounds-as President Jefferson did with those convicted under the Sedition Act; for he expressly is given the pardon power, which he may exercise for whatever reason he might choose without violence to his duty to execute the laws. (Likewise with the veto.) Presidents have no lawful power, on the other hand, to hold anyone in defiance of a court order; that is what the guarantee of habeas corpus is all about.

Equivalent reasoning legitimates Congress's declining to pass laws it-but not the judiciary-thinks would be unconstitutional, or persisting in passing measures identical or equivalent to some judicially denounced as unconstitutional. In the latter event, of course, Congress can do no more than hope that some judges will disagree with the prior judicial denunciation, and agree to enforce their laws. Cf. Van Alstyne, supra note 10, at 36-37 (arguing that Marbury v. Madison provides "no doctrine of national substantive judicial supremacy"). 
same legal questions should they occur in his business apart from that "case," even if the Executive should decide those same questions quite differently than they might be-or already had been-decided by a court.

\section{JOHN MARSHALL'S CONCEPT IN 1801}

This finality of judicial determination of a "case," with no claim of finality (that is, "judicial supremacy") as to questions decided judicially for purposes of that "case," was illustrated again in an opinion for the Court John Marshall wrote as Chief Justice less than a year after he rose to the bench. United States $v$. The Schooner Peggy ${ }^{111}$ turned on a treaty with France that called for restoration of prize ships which, as of September 30,1800, had not been "definitively condemned." The Peggy had been captured as it sailed under French authority, and before September 30 had been adjudged a lawful prize and condemned by Justice Cushing in the Circuit Court of Connecticut. No stay of execution having been sought, execution had been accomplished and avails exceeding $\$ 18,000$ had been distributed by Circuit Court order, half to the captors and half to the United States. ${ }^{112}$

Although execution had not been stayed, the claimant brought a writ of error-as the 1789 Judiciary Act allowed him to do at any time within five years after a Circuit Court judgment or decree. ${ }^{113}$ The Supreme Court held that, because its appellate process had been invoked within that period of five years, the ship "is not considered as being definitively condemned" as of September 30,1800 . On that premise, Marshall and the Court reasoned, "the schooner Peggy is within the provisions of the treaty entered into with France, and ought to be restored."114 Accordingly, they set aside the Circuit Court judgment-even though the writ of error

111. 5 U.S. (1 Cranch) 103 (1801). The Supreme Court heard argument in The Schooner Peggy during the four days prior to its December 18, 1801 issuance of the rule to show cause in Marbury v. Madison, and decided it just three days afterwards. See Erwin C. Surrency ed., The Minutes of the Supreme Court of the United States-1789-1806, 8 AM. J. LEG. HIST. 326, 338-42 (1964). Although the decision on return of the rule to show cause in Marbury would not be delivered until fourteen months later because of alteration of the Court's terms, at least at the outset, these cases were simultaneously on the Justices' minds.

112. 5 U.S. (1 Cranch) at 105-07.

113. Act of Sept. 24,1789 , ch. $20, \S 22,1$ Stat. $73,84-85$.

114. 5 U.S. (1 Cranch) at 108. 
proceedings had been commenced some months after September 30; even though no stay of execution had been either sought or granted; and even though the execution sale and the distribution of the avails had been completed long before! ${ }^{115}$

This bizarre holding left the executive branch in a quandary, not so much because the proceeds of that single ship's sale already had been distributed as because the Justices' construction of the treaty phrase "definitively condemned" would have produced enormous inequity were it generally applied. If Circuit Court condemnation decrees were to be considered not "definitive" for purposes of the treaty until the five years allowed for commencing writ of error review had elapsed, none of the French property captured during the hostilities commencing in 1797 had been "definitively condemned" by September 30,1800 . French law was not so absurd

115. Under the Judiciary Act, "writ of error" and "appeal" were distinct and different review processes. Some of the differences arose from traditional practice, and some were prescribed by the statute.

"Writ of error" was the review process of the common law, with its jury trial considerations limiting appellate review. "Appeal" had its roots in civil and international practice and, of course, admiralty, where the jury tradition was lacking. Accordingly, "appeal," unlike "writ of error," was conceived as a de novo process, the prior judgment being suspended altogether and the record being open to new and different evidence as if the prior determination never had occurred. See generally THOMAS SERGEANT, CONSTITUTIONAL LAW 36-58 ( $2 \mathrm{~d}$ ed. 1830) (discussing background of, and differences between, these procedures).

Because an "appeal" would thus automatically suspend the judgment below, precluding its execution, judgment creditors could easily suffer even if their judgments were eventually affirmed. To ameliorate this risk, the Judiciary Act placed a shorter time limit on appeals than on writs of error: An "appeal" from a District Court final decree in admiralty was allowed only to "the next" Circuit Court (i.e., to the next prescribed semiannual session of the particular Circuit Court involved). See Act of Sept. 24, 1789, ch. 20, $\$ 21,1$ Stat. at 83-84. In contrast, whereas writs of error were allowed at any time within five years, see id. $\S 22$, the interests of judgment creditors were protected because commencing a writ of error did not by itself preclude execution of the challenged judgment, nor diminish its force: A request for review by writ of error could operate as a supersedeas (staying execution) only if it was served within 10 days after judgment and was accompanied by security for damages and costs. Id. $\$ \S 22-23$.

Circuit Court decrees in admiralty, however, were made reviewable by the Act only by writ of error (within five years) by the Supreme Court, never by appeal. Act of Mar. 3,1803 , ch $40, \S 2,2$ Stat. 244 . Nonetheless, and notwithstanding the evident premise of the statute, the Justices insisted on treating even the Supreme Court's review of admiralty matters as de novo! The majority continued on this curious course for some years. See, e.g., Yeaton v. United States, 9 U.S. (5 Cranch) 281, 283 (1809).

It was this anomalous "de novo" characterization of "writ of error" proceedings in admiralty, incongruous with the five-year period allowed for initiating review, that induced the Supreme Court's ridiculous holding in The Schooner Peggy. 
as to similarly postpone the "definitiveness" of condemnation decrees; and hence any American property condemned in French courts could be retained under the treaty although every bit of French property condemned in this country had to be restored!

Attorney General Levi Lincoln thought it preposterous to so construe the treaty, and he elaborated this conviction in successive communications to President Jefferson. ${ }^{116} \mathrm{He}$ acknowledged the Court's decision in Schooner Peggy as res judicata, but counseled against taking it as authoritatively determining the point of law:

$[\mathrm{H}]$ owever this general principle may be determined, it can have little or no effect on the case of the schooner Peggy. The Supreme Court, who were competent to decide this principle, have determined it in her case. It must, therefore, be considered as binding in this particular instance. Although they have fixed the principle for themselves, and thereby bound others, in reference to the case on which they have adjudicated, it can, I conceive, extend no further. In all other cases in which the Executive or other courts are obliged to act, they must decide for themselves; paying a great deference to the opinions of a court of so high an authority as the supreme one of the United States, but still greater to their own convictions of the meaning of the laws and constitution of the United States, and their oaths to support them. ${ }^{117}$

There is no material difference between the thesis thus stated by Jefferson's Attorney General and that articulated in Congress less than two years earlier by the man who was now Chief Justice himself. More important, however, is the fact that Attorney General Lincoln's advice on the effect of the Court's decision was equally consonant with Marshall's Schooner Peggy opinion itself! Marshall emphasized that the Court's unanimous reasoning in Schooner Peggy need have no application other than for the purposes of that "case":

It is certainly true that the execution of a contract between nations is to be demanded from, and, in the general, superintended by, the executive of each nation; and, therefore, whatever the decision of this court may be relative to the rights of parties litigat-

116. 1 Op. Att'y Gen. 114 (1802); id. at 119.

117. Id. at 122 . 
ing before it, the claim upon the nation, if unsatisfied, may still be asserted. ${ }^{118}$

He maintained only that a court must independently determine the law that "affects the rights of parties litigating in court",119 and not all of their rights, but only their rights involved in that particular litigation. He acknowledged that the restoration of seized property (and the judgment whether treaty provisions require it) is an "executive [act], when viewed as a substantive act, independent of, and unconnected with, other circumstances", ${ }^{120}$ he asserted only that when judicial process is invoked and the judges' independent inquiry leads them to conclude that the treaty (or an act of Congress-for this purpose, Marshall equated the two) requires restoration, it would be "improper" for the judges to decree otherwise simply because the executive takes the view that restoration is not required. ${ }^{121}$ Marshall did not pretend any authority to control the executive's construction and execution of the treaty (or any other law) "in the general": It was only because, and only insofar as, claims were before the judges in a particular case that a court could, and must, independently and definitively determine material questions of law.

That this is precisely what Marshall (and the Court) meant is manifest from yet another feature of the case. The opinion acknowledged that the relevant treaty was not yet in force at the time the Peggy was condemned, so that the Circuit Court's condemnation decree was lawful and not erroneous when it was rendered, and so that the rights of the captors in their prize did indeed vest at that time..$^{122}$ Marshall therefore acknowledged that the treaty, as construed to set the Circuit Court judgment aside, divested property rights retrospectively. Nevertheless, he declared "if the nation has given up the vested rights of its citizens, it is not for the court, but for the government, to consider whether it be a case proper for compensation." 123

The Bill of Rights, including the Fifth Amendment with its "compensation for takings" clause, had been in force for a decade

118. 5 U.S. (1 Cranch) at 109.

119. Id. at 110 .

120. Id.

121. Id.

122. Id. at 109-10.

123. Id. 
by the time Schooner Peggy was decided; and it seems fair to assume that the Justices were generally familiar with it. Therefore, in calling it a question "not for the court, but for the government," Marshall cannot have meant that whether to compensate for that divestment was a matter for political discretion! What he must have meant, rather, was simply that no compensation claim was before the court in that case. If that was his meaning, he was only emphasizing again the same proposition that judicial competence is defined, and the authority of judicial determinations confined, not by the "question" but by the "case."

Just as plainly as rights to compensation, the rights of claimants to any ship other than the Peggy were not before the Court in that case; and that was precisely the point Attorney General Lincoln had made. The Schooner Peggy decision, erroneous though it might be, must be respected as res judicata; but, in the view of Attorney General Lincoln-and of Chief Justice Marshall-it need be regarded as nothing more.

\section{THE CONTROVERSY DURING 1802}

We now have seen that by the end of 1801 John Marshall was on record, both off and on the Supreme Court, as endorsing Madison's point that judicial authority is specific to "cases," not to "questions"-the point that distinguishes the "Jeffersonian" concept of "judicial review" from the classic Federalist "judicial supremacy" view. Shortly after the Justices concluded the term at which the Schooner Peggy case was decided, and while Marbury $v$. Madison stood on the Court's docket pending return of the rule to show cause, Congress began an extended and heated debate, in the course of which the "Jeffersonian" and the classic Federalist (and even some other) views regarding "judicial review" were publicly and prominently aired.

The period of this congressional debate found Marshall largely without official duties to perform, ${ }^{124}$ and perhaps-if he lingered in the dull new fledgling capital for eight or ten winter weeks after the end of the Court term instead of returning to his beloved

124. The 1801 Judiciary Act, to the repeal of which this debate pertained, had eliminated the Justices' Circuit Court duties. The next Supreme Court Term was not due to begin until June. Before then (although after the debate referred to here), that June Term would be cancelled by a law providing that the Supreme Court should have but one Term each year, in February. Act of Apr. 29, 1802, ch. 31, $\$ 1,2$ Stat. 156. 
Polly in Richmond and his work on the biography of Washington-he might have sat in the gallery when some of the arguments in Congress were made. Presuming that he did, Marshall's biographer Albert Beveridge effused that "Marshall's course, and, indeed, his opinion" in Marbury v. Madison "cannot be understood without a thorough knowledge of the notable debate" which took place at this time. ${ }^{125}$ Probably, as in so many other respects, Beveridge was wrong. (He certainly was mistaken in concluding that Marshall's position was the same as that which leading Federalists maintained in this debate.) Nonetheless, noting some highlights of the debate can help a reader less biased than Beveridge to distinguish between Marshall's view and that which he was mistakenly believed to have shared.

Four days before the House in February 1801 voted the contested Presidency to Jefferson over Burr, President Adams had signed a measure substantially overhauling the federal judicial system, making changes that lawyers had been urging for years. ${ }^{126}$ The Judiciary Act of $1801^{127}$ basically was a non-partisan measure, and some changes first introduced by it were later reinstituted by Republican Congresses after its 1802 repeal. But the 1801 Act also had a provision which precipitated partisan reaction: It multiplied the number of federal judgeships, eliminating the Justices' circuit-riding duty and staffing the six Circuits (which replaced the previous three) with sixteen new Circuit Judges. ${ }^{128}$

Adams's lame duck appointment of Federalists to all of these new positions irritated even those Republicans who had favored the reforms, and outraged those convinced that the costly new judgeships were unnecessary at best. But some of Adams's appointees declined, and perhaps for a time Jefferson was satisfied that replacing them (and others, as vacancies occurred) with good Republicans would sufficiently redress Federalist domination of the courts. Within the year, however, Jefferson became committed to

125. See 3 BEVERIDGE, supra note 72 , at 50 .

126. I discuss the frustrations lawyers experienced under the original system, and the course of efforts at reform, in a manuscript not yet ready for publication, tentatively entitled "The Pyramidization of the Judiciary."

127. Act of Feb. 13, 1801, ch. 4, 2 Stat. 89 (repealed 1802).

128. Three were to sit together on each of five Circuit Courts, and one for the Sixth Circuit (covering Tennessee, Kentucky, and Ohio) was to sit as the Circuit Court with the District Judges for Tennessee, Kentucky, and Ohio in turn. Id. $\S \S 6-7,2$ Stat. at 90. 
the 1801 Act's repeal. Debate on the repeal bill continued through January and February into the first days of March 1802, and was extensively reported by the press. ${ }^{29}$

Repeal would abolish the new judgeships, depriving incumbent judges of their offices; and this, ran the argument of principal Federalists in the Senate, would subvert the guarantee of life tenure, thereby destroying the independence essential to the judiciary's role as guardian of the Constitution. ${ }^{130}$ Republican senators answered by denying that repeal would threaten judicial independence and by reiterating the fundamental point both Madison and Marshall already had separately made. Senator Wright of Maryland, for example,

admitted . . . that judges ought to be the guardians of the Constitution, so far as questions were constitutionally submitted to them; but he held the Legislative, Executive, and Judiciary, each severally the guardians of the Constitution, so far as they were called on in their several departments to act; and he had not supposed the judges were intended to decide questions not judicially submitted to them, or to lead the public mind in Legislative or Executive questions .... ${ }^{31}$

Near the end of the Senate debate, Republican John Breckenridge of Kentucky stated a markedly different thesis: that the Constitution gives each department "exclusive authority on the subjects committed to it," and "that therefore the Legislature have the exclusive right to interpret the Constitution, in what regards the law-making power, and the judges are bound to execute the laws they make."132 This was by no means the "Jeffersonian" view, which most of the Republicans shared; but Senator

129. See 3 BEVERIDGE, supra note 72 , at 92 .

130. See, e.g., 11 ANNALS OF CONG. 31-33 (1802) (remarks of Senator Jonathan Mason, Federalist from Massachusetts); id. at 38-39, 83, 87, 89 (remarks of Senator Gouverneur Morris, Federalist from New York); id. at 56-57 (remarks of Senator Uriah Tracy, Federalist from Connecticut); id. at 131 (remarks of Senator Nathaniel Chipman, Federalist from Vermont); id. at 163-64, 166-67 (remarks of Senator James Ross, Federalist from Pennsylvania); id. at 174-76 (remarks of Senator Aaron Ogden, Federalist from New Jersey).

131. Id. at 115. If carried as far as the most troubled of the Federalists would take it, Stevens Mason of Virginia added, judicial independence "will, I fear sir, ... soon become something like supremacy." Id. at 63. Mason denied that the Constitution "authorizes our courts of justice to control the other departments of the Government." Id. at 59 (emphasis added).

132. Id. at 179. 
Breckenridge's thesis gave House Federalists a pretext to claim that Republicans pretended "that the judges have no right to declare a law to be unconstitutional; that no such power is given to that branch in the Constitution."133 This precipitated the Federalists' adamant recitals of the "judicial supremacy" view.

New York Federalist Gouverneur Morris, for example, erupted before the Senate vote was taken: "The decision of the Supreme Court is, and, of necessity, must be final. This, Sir, is the principle, and the source of the right for which we contend."134 In the House, although some of the Federalists were temperate in maintaining this view, ${ }^{135}$ more of them fulminated with panegyrics and rhetorical flourish. ${ }^{136}$

Fundamental to the Federalists' judicial supremacy thesis was the assumption that a single, definitive, authoritative determination of constitutional questions must be (and could be) had. ${ }^{137}$ Those

133. Id. at 542 (remarks of Congressman Joseph Hemphill, Federalist from Pennsylvania); see also id. at 529 (remarks of Congressman Archibald Henderson, Federalist from North Carolina); id. at 783 (remarks of Congressman Roger Griswold, Federalist from Connecticut); id. at 920, 926 (remarks of Congressman Samuel Dana, Federalist from Connecticut).

134. Id. at 180 .

135. E.g., North Carolina Federalist John Stanley; id. at 574.

136. E.g., Connecticut Federalist Samuel Dana; id. at 932.

North Carolina Federalist William Hill conjured the vision of a keeper driving some raging animal back to its cage, saying the judges

are intended to stand between the Legislature and the Constitution, between

the Government and the people; they are intended to check the Legislature.

Should the Legislature even surmount the barrier of the Constitution, it is the

duty of the judges to repel it back within the bounds which limit its power.

Id. at 859. South Carolina Federalist John Rutledge, Jr. maintained that "the great interests of the people will be safe" from legislative or executive offenses only because "[a]ny such attempt would be checked by the judges, who are designed by the Constitution to keep the different branches of the Government within the spheres of their respective orbits, and say, thus far you shall legislate, and no farther." Id. at 740. And in one of the finer flourishes embellishing the long and tedious days of repetitive debate, Rutledge added:

The people of America say in their Constitution, the Judiciary is designed as a check upon the Legislature and Executive, and as a barrier between the people and the Government. We say it is the sheet-anchor which will enable us to ride out the tornado and the tempest, and that if we part from it there is no safety left; that it is the only thing which can preserve us from the perilous lee-shore, the rocks and the quicksands, where all other Republics have perished. The Judiciary is the ballast of the national ship; throw it overboard and she must upset.

Id. at 743 .

137. Connecticut Federalist Samuel Dana, for example, said, "a fair construction of the Constitution" should "be uniformly secured." Id. at 929. 
Republicans who inclined toward the Breckenridge thesis shared the same assumption; ${ }^{138}$ they differed only as to who should deliver that authoritative exposition, that "true meaning" to be accepted by all.

The more careful Republicans, however, adhered to the orthodox "Jeffersonian" view and thus drew the same distinctions that Madison-and Marshall-had drawn. Republican John Bacon of Massachusetts, for example, rose to say:

However I may differ in opinion from some with whom I have the honor generally to agree, I may not deny, but must frankly acknowledge the right of judicial officers of every grade to judge for themselves of the constitutionality of every statute on which they are called to act in their respective spheres. This is not only their right, but it is their indispensable duty thus to do. Nor is this the exclusive right and indispensable duty of the Judiciary department. It is equally the inherent and the indispensable duty of every officer, and I believe I may add, of every citizen of the United States. The Constitution is emphatically the law of the land .... It is indeed paramount with us to all other human laws that can be made. ${ }^{39}$

And Vermont Republican Israel Smith, who had served as chief justice of his state's supreme court, stated:

It is true your judges have authority, derived from the nature of their power as judges, to decide in this way..... [It is their] duty to decide a law void, which directly infringes the Constitution. When there is a constitution of government, this principle is inseparably united with the judiciary authority .... [T] hey are left to maintain a perpetual, but ineffectual combat, against the effects of such laws. ${ }^{140}$

138. E.g., "The decision of a Constitutional question must rest somewhere," id. at 661 (Virginia Republican John Randolph); "That there must be some place where the true meaning of the Constitution must be determined, all would agree," id. at 531 (North Carolina Republican Robert Williams-who was, of course, wrong in believing that "all would agree").

139. Id. at $982-83$. He continued:

The Judiciary are so far independent of the Legislative and Executive departments of the Government, that these, neither jointly or separately, have a right to prescribe, direct, or control its decisions. It must judge for itsclf, otherwise the decisions made in that department would not be the decisions of that, but of some other department or body of men. The Constitution, and the laws made pursuant thereto, are the only rule by which the Judiciary, in their official capacity, are to regulate their conduct.

Id. at 983.

140. Id. at 698-99. A few Republicans quibbled over the use of terms such as "null" 
"It might as well be said," added Smith, that "this was an evil inseparable from judicial authority, as to call it a salutary principle of the Constitution." ${ }^{141}$

These congressmen understood that it is not required, and must not be expected, that every constitutional question have one authoritative answer. Certainly once a dispute has been judicially decided, the rights of those parties in that particular matter disputed are finally resolved. ${ }^{142}$ But the judicial disposition of a litigated case resolves nothing for non-parties, or about matters other than those there particularly in dispute.

These congressmen understood that trusting each federal department to do its own job without a single, authoritative determination of constitutional questions does not, in the real and practical world, portend hopeless cacophony; moreover, they recognized that this indeterminacy itself might help restore such judicial modesty and prudence as had made constitutional determinations by the judiciary seem so acceptable eight, ten, and fifteen years before. Certainly judges must disregard laws they deem unconstitutional, observed Vermont's former chief justice Smith:

but prudent judges will exercise this right with great caution, knowing the Legislature has an equal right to put constructions; they will also consider the Legislature are obliged to precede them in their construction. The evil resulting from a difference in

and "void." Kentucky Republican Thomas Davis said, for example, "I am willing to admit ... that judges thinking a law unconstitutional are not bound to execute it; but not to declare it null and void." Id. at 558. Similarly, Virginia Republican Phillip Thompson said that judges "may, to be sure, for a while impede the passage [that is, effect] of a law, by a decision against its constitutionality; yet, notwithstanding the law is in force, is not nullified, and will be acted upon whenever there is a change of opinion." Id. at 553.

Most, however, while agreeing with their point, did not scruple against the practical expedient of using the easier, familiar mode of expression. See, e.g., id. at 698 (Vermont Republican Israel Smith). Federalist Congressman Calvin Goddard of Connecticut adverted to the verbal quibble. See id. at 727 .

141. Id. at 698 .

Some more extensive excerpts from this congressional debate can be found in James M. O'Fallon, Marbury, 44 STAN. L. REV. 219, 224-38 (1992). Professor O'Fallon, however, overemphasizes the Breckenridge "legislative supremacy" view (which O'Fallon seems to think predominated among the Republicans), and neglects entirely what is characterized here as the "Jeffersonian" view.

142. As Vermont's Israel Smith observed, "Congress not only can have no pretensions for assuming and exercising Judicial powers, but the manner in which they are organized utterly forbids it. Congress, sitting as a court of judicature, would immediately become contemptible ...." 11 ANNALs OF CONG. 699 (1802). 
opinion cannot escape them. Hence it has been said, that the judges, in deciding the question on the carriage $\operatorname{tax}^{143}$ observed they never would exercise this right, unless this law and the Constitution were absolutely irreconcilable. ${ }^{144}$

\section{JOHN MARSHALL'S CONCEPT IN 1803: MARBURY V. MADISON}

We do not know what prompted John Marshall to set forth so elaborately in Marbury $v$. Madison his rationale for the already "long and well established" ${ }^{45}$ practice we call "judicial review." Probably it was simply another manifestation of his comprehensively systematic habit of mind. Perhaps, however, the appearance a year earlier of the striking new thesis propounded by Senator Breckinridge made the reaffirmation of older, traditional propositions seem desirable. But if the previous winter's highly publicized congressional debate was a factor inducing the Marbury opus, the most significant fact of all is that nothing whatsoever in John Marshall's famous opinion affirms the "judicial supremacy" thesis that the leading Federalists had staked for themselves in that debate. ${ }^{145}$ One Associate Justice who also sat for Marbury

143. This reference was to Hylton v. United States, 3 U.S. (3 Dall.) 171 (1796); see supra note 24.

144. 11 ANNALS OF CONG. 698 (1802).

145. 5 U.S. (1 Cranch) 137, 176 (1803).

146. Professor O'Fallon suggests that Marbury was "deeply embedded" in the partisan turmoil over repeal of the 1801 Judiciary Act, O'Fallon, supra note 141, at 252, and that "[t]he political struggle between Federalists and Republicans was powerfully at work as Marshall moved to the closing act of Marbury, the defense of judicial review," $i d$. at 256.

I disagree. Obviously everyone involved in Marbury was aware of the previous winter's repeal debate; but Professor O'Fallon's suggestion derives from his mistaken impression that "Marshall's adherence to core Federalist doctrine was unwavering," id. at 250 , that "[h]is vindication of judicial review was the hackneyed litany of the Federalists in the repeal debates, shorn of its rhetorical flair," id. at 256, and that "Marshall's opinion in Marbury was loyal to this [Federalist] vision," id. at 258.

O'Fallon rightly rejects Robert McCloskey's absurd, romanticized account of Marshall's opinion as a "masterwork of indirection," see ROBERT MCClOSKEY, THE AMERICAN SUPREME COURT 40 (1960); but still O'Fallon remains too charmed by the persistent mythology that prevents taking this fair and much loved man of integrity, modesty, and candor on his own (albeit fallibly human) terms.

For example, when Marshall wrote to Justice Paterson referring to the dictates of "policy" and said, "Judges however are of all men those who have the least right to obey her dictates," Letter from John Marshall to William Paterson (May 3, 1802) in 6 THE PAPERS OF JOHN MARSHALl 117 (Charles F. Hobson and Fredrika J. Teute eds., 1990) [hereinafter PAPERS OF MARSHALLl, I think he really meant it. Professor O'Fallon 
had explicitly propounded "judicial supremacy" before ${ }^{147}$-but he did not write the Marbury opinion! Instead, the opinion prominently employed the distinction that Marshall-like Madison-had consistently emphasized before, which it had fallen to Jeffersonian congressmen to stress in the congressional debate the previous year: the distinction between "question" and "case."

The more significant sentence in the Marbury opinion is not the celebrated first one quoted here, but rather the sentence Marshall immediately subjoined: "It is emphatically the province and duty of the judicial department to say what the law is. Those who apply the rule to particular cases, must of necessity expound and interpret that rule." 148 . This emphasis on "case" continues throughout the ensuing paragraphs of Marshall's opinion:

So if a law be in opposition to the constitution; if both the law and the constitution apply to a particular case, so that the court must either decide that case conformably to the law, disregarding the constitution; or conformably to the constitution, disregarding the law; the court must determine which of these conflicting rules governs the case. This is of the very essence of judicial duty.

If, then, the courts are to regard the constitution, and the constitution is superior to any ordinary act of the legislature, the constitution, and not such ordinary act, must govern the case to which they both apply.

The judicial power of the United States is extended to all cases arising under the constitution.

Could it be the intention of those who gave this power, to say that in using it the constitution should not be looked into?

apparently thinks he did not.

147. Justice Chase, sitting at Circuit, had declared that judicial opinions on constitutional questions are binding beyond the parties to a particular case, and even suggested that construing the Constitution was exclusively a judicial task. See Case of Fries, 9 F. Cas. 924, 932-33 (C.C.D. Pa. 1800) (No. 5127) (Chase, J., addressing convicted defendant); United States v. Callender, 25 F. Cas. 239, 256 (C.C.D. Va. 1800) (No. 14,709) (Chase, J., addressing counsel); see also the entry in Justice Chase's "Charge Book," quoted in GOEBEL, ANTECEDENTS, supra note 7, at 647 (stating that courts are the "only proper and competent authority" to decide the constitutionality of state and federal laws). The late Justice Iredell, and also District Judge Peters, had endorsed this view as well. See Case of Fries, 9 F. Cas. 826, 911 (C.C.D. Pa. 1799) (No. 5126) (Iredell, J., charging petit jury); id. at 908 (charge of District Judge Peters).

I know of no evidence that Justice Cushing, Justice Paterson, Justice Washington, or Justice Moore had endorsed judicial supremacy; and certainly Marshall had not.

148. 5 U.S. (1 Cranch) at 177 (emphasis added). 
That a case arising under the constitution should be decided without examining the instrument under which it arises?

This is too extravagant to be maintained. ${ }^{149}$

Had the distinction not been so prominently featured in public debate only a few months before, or even had it not been so emphasized by Marshall himself as the linchpin of his argument against the censure of Adams in 1800, it might be credible to suggest that this scrupulous care to speak always in terms of a "case" and to eschew any claim of competence to more broadly decide a "question" was only mere happenstance. But against the backdrop of what actually had occurred, and of the contrary opinions very prominently maintained, it requires an exercise of will to deny the significance of Marshall's choice of words. His point-in Marbury as it had been consistently before-was that the judiciary's determination of constitutional questions is limited both in opportunity and in authoritative impact to a particular "case."

Marshall observed in Marbury that the Court's decision in the 1794 Chandler case, which held the 1792 Pension Act unconstitutional, ${ }^{150}$ "is understood to have decided the merits of all claims of that description ...."151 But many veterans not involved in that litigation had been certified by the process held unconstitutional in Chandler, and the Secretary of War and the Congress certainly remained unrestrained from including them when they composed the pension list. For the future, however, recognizing that the Justices would no longer participate in the certification process prescribed by the 1792 Act, Congress intelligently chose acclimation over impasse, and enacted a new law under which veterans eligible for pensions were to be certified in a different way. ${ }^{152}$ That is why, as Marshall noted, after Chandler, claimants "found it necessary to pursue the mode prescribed by the law subsequent to that which had been deemed unconstitutional, in order to place themselves on the pension list." ${ }^{\text {"153 }}$ Hence, notwithstanding the Court's decision in Todd (the companion Pension Act case), ${ }^{154}$ no person except Todd who had actually received pen-

149. Id. at 178-79 (emphasis added).

150. See supra note 18 .

151. 5 U.S. (1 Cranch) at 172.

152. Act of Feb. 28, 1793, ch. 17, 1 Stat. 324.

153. 5 U.S. (1 Cranch) at 172.

154. See supra note 18 . 
sion money pursuant to a certification like Todd's could be obliged to return it, unless by court order in a "case" to which that person were party-for the same reason that no ship, other than the schooner Peggy (or its avails), libelled and condemned during the French hostilities need be restored unless that vessel's claimant secured judgment in his own "case" from some court that followed the Schooner Peggy rationale.

Thirteen other Justices of the Peace had declined to join William Marbury and his co-petitioners in their quest for mandamus relief. Had the relief sought in the Marbury case been awarded, it would not have-it could not have-obliged the executive to deliver their commissions to those thirteen non-parties. Any of them, of course, could have brought his own "case," and then a mandamus for him might have issued as well, if the facts were no different and the judges maintained the same view; and any such order must then have been obeyed. But from any non-litigant, albeit identically circumstanced, the executive could rightly continue to withhold the commission, if in his independent opinion the Court in Marbury's "case" had decided the question wrongly.

This is the view taken by Madison at the Constitutional Convention and in Congress. It is the view stated by Vermont's former chief justice Smith and other mainline Republicans during the congressional debate in 1802. It is the view Andrew Jackson would take in explaining his veto of the Bank of the United States recharter, ${ }^{155}$ and Abraham Lincoln would take with reference to the infamous Dred Scott decision. ${ }^{156}$ It is the classic "Jeffersonian" view; and it is the view that John Marshall-in Marbury, as well as when a congressman and in the Schooner Peggy case-maintained.

It should not be surprising, if one puts aside the fictions modern writers have spun about him, that Marshall held so "Jeffersonian" and anti-Federalist a view on this particular point. ${ }^{157}$ As a

155. Veto Message from Andrew Jackson to the Senate (July 10, 1832), in 2 JAMES D. Richardson, MEssages aNd PAPERS of THE PREsidents 576, 581-82 (Washington, D.C., Government Printing Office 1899).

156. Campaign Speech by Abraham Lincoln (July 17, 1858), in 2 THE ColleCted WORKS OF ABRAHAM LINCOLN 504, 516-17 (Roy P. Basler ed., 1953) [hereinafter CoLLECTED WORKS OF LINCOLN]; Debate with Stephen Douglas (Oct. 13, 1858), in 3 CoLLECTED WORKS OF LINCOLN, supra, at 255; First Inaugural Address (March 4, 1861), in 6 RiCHARDSON, supra note 155 , at 5, 9-10.

157. The affable, mild, and fair-minded Chief Justice and the suspicious, spiteful, parti- 
congressman, Marshall had been considered a maverick, even frustrating Federalist partisan machinations. His election-campaign disavowal of the Alien and Sedition Acts had "aroused a storm of protest from" other Federalists; ${ }^{158}$ and in January 1800 , his vote against his party on a Republican resolution to repeal the most obnoxious part of the Sedition Act had caused the resolution to pass by a two-vote margin. ${ }^{159}$ In March of the same year, when the House received the "Disputed Elections Bill" conjured up by Senate Federalist's to ensure their party's success in the upcoming presidential election, despite importuning by Federalist leaders Marshall caused the bill to be so amended as to frustrate its partisan purpose, effectively killing the measure. ${ }^{160}$

Moreover, his snub of the "judicial supremacy" view is not even the only example in the Marbury opinion itself of Marshall's preferring a Jeffersonian rationale to a Federalist one. He would not have reached the constitutional issue in that case but for his premise that the categories of "appellate" and "original" jurisdiction under Article III are mutually "exclusive"-a premise Mar-

san President might have shared almost nothing else in common, apart from their Virgimia origins; but on this point, they-and also Madison-manifestly agreed. To be sure, Jefferson was irreconcilably hostile to the holding in Marbury v. Madison; but his opposition was unrelated to the proposition (or its rationale) that courts must independently decide constitutionality for purposes of any "case."

It is clear . . . that Jefferson's hostility was due solely to the fact that Marshall had sought to interfere with the function of the Executive in making appointments, and after holding the [mandamus jurisdiction] statute unconstitutional had proceeded by obiter dicta to deliver a lecture to the President as to the rights of appointees to office.

1 WARREN, supra note 17, at 264. Jefferson maintained that a commission to office, like a deed, took effect only upon delivery; and he denounced the contrary doctrine (which Marbury took to warrant mandamus) as wrong in point of law and "merely an obiter dissertation of the Chief Justice." Letter from Thomas Jefferson to Justice William Johnson (June 12, 1823), in 15 WRITINGS OF JEFFERSON, supra note 71, at 439, 448.

Jefferson hoped that certain issues concerning discovery of executive documents in the 1807 treason trial of Aaron Burr would provide occasion to rectify the mischievous dicta. See Letter from Jefferson to Hay, supra note 73, at 213. But Marshall himself presided at the Burr trial, and issued a subpoena for the documents sought by the defense. United States v. Burr, 25 F. Cas. 30 (C.C.D. Va. 1807) (No. 14,692d); see also United States v. Burr, 25 F. Cas. 187 (C.C.D. Va. 1807) (No. 14,694).

Additional insight into the true nature of Jefferson's objection to the Marbury decision is provided by his Attorney General's critique of Justice Johnson's mandamus in Gilchrist v. Collector of Charleston, 10 F. Cas. 355, 358 (C.C.D.S.C. 1808) (No. 5420); see 1 WARREN, supra note 17 , at $330-31$.

158. LEONARD BAKER, JOHN MARSHÁLL: A LIFE IN LAW 306 (1974).

159. 10 ANNALS OF CONG. 419 (1800).

160. See 2 BEVERIDGE, supra note 72 , at $452-58$. 
shall characterized as "obvious" and necessary to prevent the words being "mere surplusage," and "form without substance."161 But that clearly fallacious premise ${ }^{162}$ was at the time a Republican, not a Federalist, one. ${ }^{163}$

Popular mythology dishonors this straightforward man by depicting him as a master of subtle statecraft. ${ }^{164}$ Marshall was a warm, congenial colleague, disciplined in his habits of mind (although preferring leisure to labor and easing back from his duties whenever he conscientiously could). He possessed a self-effacing charm and good humor that made him attractive as a leader, his character and talents inspiring (except in such bitter folk as Jefferson) trust and affection alike. ${ }^{165} \mathrm{He}$ was not wont to cajole, or

161. Marbury v. Madison, 5 U.S. (1 Cranch) 137, 174-75 (1803).

162. The premise is contraindicated by the records of the Constitutional Convention-which, of course, were unknown to Marshall because they had not yet been published. For further explanation, see David E. Engdahl, Federal Question Jurisdiction Under the 1789 Judiciary Act, 14 OKLA. CITY U. L. REV. 521, 539-40 (1989).

The fact that this crucial step in his Marbury rationale was fallacious does not justify scurrilous accusations like that of Professor Sanford Levinson that Marshall was being "intellectually dishonest" and "untruthful." Sanford Levinson, Law as Literature, 60 TEX. L. REV. 373, 389 (1982). Professor Levinson and I each, I ain sure, similarly have taken some untenable positions now and then, in absolute candor.

163. It had been urged, for example, by Republican Congressman Thomas Davis of Kentucky in the 1802 debate on repeal of the 1801 Judiciary Act. See 11 ANNALS OF CoNG. 556 (1802). Davis was answered by Federalist Congressman Samuel Dana of Connecticut, id. at 903 .

164. See, for example, McCloskey's wholly inapt characterization of the Marbury opinion as a "masterwork of indirection, a brilliant example of Marshall's capacity to sidestep danger while seeming to court it, to advance in one direction while his opponents are looking in another." MCCLOSKEY, supra note 146, at 40.

165. After Marshall's death, a meeting was held in the federal courtroom in Richmond, and a resolution expressing "sentiments of love and veneration for the judge, and the man," was unanimously adopted, with a preamble as follows:

[T] he bench, bar, and officers of the court, assembled at the present term, embrace the first opportunity to express their profound and heartfelt respect for the memory of the venerable judge, who presided in this court for thirty-five years, ... with such indulgence to counsel and suitors, that every body's convenience was consulted, but his own, ... with such striking impartiality and justice, and a judginent so sure, as to inspire universal confidence, ... with such modesty, that he seemed wholly unconscious of his own gigantic powers, - with such equanimity, such benignity of temper, such amenity of manners, that not only none of the judges, who sat with him on the bench, but no member of the bar, no officer of the court, no juror, no witness, no suitor, in a single instance, ever found or imagined, in any thing said or done, or omitted by him, the slightest cause of offence .... The unaffected simplicity of his manners; the spotless purity of his morals; his social, gentle, cheerful disposition; his habitual self-denial, and boundless generosity towards others; the strength and constancy of his attachments; his kindness to his friends and neighbors; . . . his benevolence towards all men, and his ever active beneficence; these amiable qualities shone so conspicuously in him, throughout his life, that highly as he 
impose his opinions ${ }^{166}$ upon others. ${ }^{167}$ Although capable of very strong convictions, Marshall was an eminently fair and pragmatic man, candidly open to rational persuasion and ready to weigh alternative views fairly. ${ }^{168} \mathrm{He}$ strongly believed in national authority, but also in its limitation-under a Constitution that does, in fact, grant the national government great, but enumerated and limited powers. He was not a "result-oriented" judge.

That Marshall wrote most of the Supreme Court's opinions after abandoning the seriatim tradition suggests, not that Marshall dominated the other minds on the Court, but rather that Marshall's colleagues (most of whom had strong intellectual talents of their own) acknowledged his peculiar forensic skill, and trusted him to articulate and elucidate the consensus emerging from their deliberations-even sometimes when he personally disagreed. ${ }^{169}$. That peculiar forensic skill was excellence not at original, but at comprehensive and systematic argumentation. A colleague, twenty years intimately familiar with his work, wrote that Marshall's "expositions of constitutional law ... remind us of some mighty river ... which, gathering in its course the contributions of many

was respected, he had the rare happiness to be yet more beloved.

$30 \mathrm{~F}$. Cas. at 1326 . Duly discounted (as a eulogy should be), this still is a fair measure of the man. See also BAKER, supra note 158, at 702-04 (describing Marshall's personal relationships with the other Justices).

166. Albert Beveridge assumed, without any evidence, that Marshall must have "persuaded" the (obviously?) "lesser" minds of the other Justices to their Marbury view. See 3 BEVERIDGE, supra note 72, at 127-28.

167. When the 1802 repeal reinstituted circuit-riding under the 1801 Judiciary Act, Marshall held "some strong constitutional scruples" against the same set of Justices sitting on Circuit and Supreme Courts, thus performing both trial and appellate functions (whether or not in the same case). He corresponded extensively with the other Justices on this point during 1802. But his letters were deferential in tone, and after reflection he readily acquiesced in the majority's opinion-which differed from his own. See GEORGE L. HASKINS \& HERBERT A. JOHNSON, 2 HISTORY OF THE SUPREME COURT OF THE UNITED STATES: FOUNDATIONS OF POWER: JOHN MARSHALL, 1801-15, at 169-77 (Paul A. Freund gen. ed., 1981).

168. Further illustrating his openness to persuasion by others' reasoning, Marshall wrote in an 1804 opinion: "I confess the first bias of my mind was very strong . . . . I was much inclined to think .... I was strongly inclined to think . . . . But I have been convinced that I was mistaken, and I have receded from this first opinion. I acquiesce in that of my brethren ....." Little v. Barreme, 6 U.S. (2 Cranch) 170, 179 (1804).

169. William Johnson, joining the Court in 1804, was surprised that the practice was for Marshall to deliver the opinion in all cases in which he participated, "even in some instances when contrary to his own judginent and vote." Letter from William Johnson to Thomas Jefferson (Dec. 10, 1822), quoted in DONALD G. MORGAN, JustiCE WILliaM JOHNSON-THE FIRST DISSENTER 181-82 (1954). 
tributary streams, pours at last its own current into the ocean, deep, clear, and irresistable." ${ }^{\prime 70}$ Hence one can find in Marshall's Marbury opinion the ideas and even the phrases of others: not only of Hamilton, but also of Madison, St. George Tucker, and other Virginians, like Roane and-yes-even Jefferson. But (to keep the "river" metaphor), the Federalist notion of "judicial supremacy" was-at least at this time ${ }^{171}$-beyond Marshall's watershed.

Almost two years after Marbury, Chief Justice Marshall wrote Justice Chase (who then was undergoing the ordeal of impeachment proceedings), suggesting that the remedy "of impeachment shoud yield to an appellate jurisdiction in the legislature. A reversal of those legal opinions deemed unsound by the legislature woud certainly better comport with the mildness of our character than a removal of the Judge who has rendered them unknowing of his fault." ${ }^{\prime 12}$ There still persists the impression (mistaken, in my view) that Marshall in this letter was suggesting "legislative review of judicial decisions."173 That was the view of Marshall's myopic biographer, Albert Beveridge, who recoiled from this statement in disbelief and dismay, calling it "the most radical method for correcting judicial decisions ever advanced, before or since .... Had we not the evidence of Marshall's signature to a letter written in his well-known hand, it could not be credited that he ever entertained such sentiments." "174 Beveridge was correct in observing that this statement was "utterly destructive of the Federalist philosophy of judicial control of legislation"; 175 however, it by no means follows, as Beveridge also exclaimed, that it is "in direct contradiction to [Marshall's] reasoning in Marbury vs. Madison ...."176 Once one recognizes (as Beveridge-and also

170. STORY, supra note 6 , at iii-iv.

171. We are concerned here only with John Marshall's views at and proximate to the time of Marbury v. Madison. What might have occurred after he came under the influence of that bullheaded genius Joseph Story, see supra note 6, must be deferred to a subsequent article.

172. Letter from John Marshall to Samuel Chase (Jan. 23, 1805 [misdated 1804]), in 6 PAPERS OF MARSHALL, supra note 146, at 347. The letter in Marshall's own handwriting is reproduced in 3 BEVERIDGE, supra note 72 , at 176-77.

173. See, e.g., O'Fallon, supra note 141, at 241.

174. 3 BEVERIDGE, supra note 72 , at 178.

175. Id.

176. Id. 
McCloskey ${ }^{17}$-of course failed to do) the "Jeffersonian" character of Marshall's Marbury rationale, there is no contradiction at all.

Although he used the phrase "appellate jurisdiction,",178 Marshall's statement to Justice Chase only concerned "legal opinions." Impeachment-the expedient for which Marshall's alternative specifically was ventured-might be used to get rid of one who decided legal questions the "wrong" way, but it could not possibly affect any "case" already decided. It seems unlikely that Marshall had in mind an alternative that would go further, abridging that "finality" of adjudication (in the res judicata sense) deemed indispensable ${ }^{179}$ to a body's being regarded as "judicial." More likely, in suggesting "reversal of those legal opinions deemed unsound by the legislature," Marshall conceived of establishing, for future application, answers to legal "questions" which were different from those which judges had employed in deciding some particular case or cases brought before them. ${ }^{180}$

On this view, the suggestion ventured to Chase indicates that Marshall might have found acceptable an arrangement under which constitutional questions could be resolved by a popularly responsible branch, so long as the judges were left independently to adjudicate cases in accord with their own understanding of the resolutions thus politically made. That would not differ materially from the arrangement under which judges decide independently in accord with statutes-unless on the premise (which, as we now have learned, Marshall did not share with other Federalists) that the judiciary was somehow vested with special and unique responsibility for safeguarding the Constitution. Accordingly, his letter to Chase is simply more proof that Marshall was unpersuaded by the Federalist view, ${ }^{181}$ and again underscores the distinction between

177. See MCCloskey, supra note 146.

178. And although he invoked a comparison to the ancient practice of attaint, which could reverse a verdict as well as punish the jurors. See BLACKSTONE, supra note 8 , at bk. 3, ch. 25.

179. See supra note 115 .

180. This would somewhat resemble a suggestion Madison had made in 1788 in response to the constitution Jefferson had proposed for Virginia. Madison had suggested that a law deemed unconstitutional by the "Council of Revision" be suspended until repassed by extraordinary majority after an intervening election, and that it should "not be allowed the Judges . . . to pronounce a law thus enacted unconstitul \& invalid." $O b$ servations on the 'Draught of a Constitution for Virginia', in 5 THE WRITINGS OF JAMES MADISON 284, 294 (Gaillard Hunt ed., 1904).

181. Of course, it also is possible that this passing comment of a warm and compas- 
independence in the disposition of cases and the Federalist notion of judicial supremacy on constitutional and other legal questions.

\section{CONCLUSION}

Few readers, I expect, will find immediately credible my suggestion that the thoughtful, practical, and realistic John Marshall could have contemplated without horror an idea as tolerant of disuniformity, disagreement, and uncertainty in constitutional interpretation as this. ${ }^{182}$ It is possible, perhaps, that we have been mistaken in attributing to Marshall the virtues of practical intelligence and sound judgment, and that Marshall's endorsement of this harebrained "Jeffersonian" notion, now disclosed, should discredit the heretofore venerated Chief Justice. But I do not think so.

We too easily read our history to validate familiar practices we lack sufficient imagination to improve. We should rather explore it to discover whether and how we have misplaced alternatives that might more happily serve us even now. If so intelligent and practical a statesman as Marshall found the herein-discussed "Jeffersonian" concept to have merit, that should prompt us to reflect upon it hospitably, not to withdraw.

In a previous article I put forward the unsettling discovery that the pyramidic hierarchy now familiar in the federal judiciary neither is constitutionally required, nor existed in fact at the outset. It developed gradually from a combination of circumstances, and did not become characteristic until well after the period of Marbury. ${ }^{183} \mathrm{~A}$ few of the contributing circumstances were deliber-

sionate man in a sympathetic letter of support to a distressed friend was too casual, too tentative, or too little thought-out to bear any of the grand import we well-meaning scholars endeavor to freight it with.

182. The predictable response to this "Jeffersonian" thesis, when it has received insufficient reflection, is to call it "a stance fraught with difficulties for the effective functioning of government." O'Fallon, supra note 141, at 244.

183. See generally Engdahl, supra note 36 .

At the time, both in England and in the several American states, the word "supreme" was most commonly used to denote trial tribunals of broad territorial and subject matter jurisdiction, few of which had regularized or substantial appellate roles. In the federal Constitution, the Framers in effect implemented the Virginia Plan's proposal of "one or more supreme" federal tribunals, see 1 RECORDs, supra note 9, at 21 (emphasis added), by providing for a jurisdiction as broad as Article III, but leaving Congress to decide whether any more than a single tribunal should comprise that judiciary; if so, what should be the territorial and subject matter competence of each; and what, if any, appellate role any should have with respect to the actions of any other. 
ate, but the most significant were inadvertent. ${ }^{184}$ Because of this inadvertence, and because Blackstonian lawyers did not conceive of courts as public policy organs, there was scant reflection and no public choice at the outset regarding any political consequences of pyramidization. However, when later a conscious judicial instrumentalism came to be part of the American political experience, ${ }^{185}$ those at the top of the judicial pyramid were positioned to dominate large segments of public policy. Not even pyramidization itself had been chosen with such a regime in mind; but the profound changes were gradual and subtle enough that the judiciary's resulting political role was not universally recognized, and never was presented for public deliberation and choice.

The thesis of this present article is a cognate one.

Most ordinary Americans probably assume (if thinking of such things at all) that a "last word" on "constitutional" questions must come from the Supreme Court for the same reason they assume the number of Justices must be nine. Lawyers and statesmen must be expected to ponder the points somewhat more. I challenge all who read this Article to doubt along with me (and with John Marshall), and to undertake seriously to question and debate whether "judicial supremacy" is necessary or even makes sense.

Without it, of course, the whole multiplex enterprise of "legitimating" the Cooper v. Aaron model of "judicial review"-by discussions of "institutional competence," "185 "validation,"187 "neutral principles,"188 "original intent,"189 "representation reinforce-

The First Congress opted for an array of federal courts, but shared Madison's view that forums of first instance should have "final jurisdiction in many cases." See id. at 24. Thus, the Judiciary Act of 1789, 1 Stat. 73, foreclosed appellate review of most cases commenced in Circuit Courts (the federal trial courts of most general jurisdiction), and restricted and encumbered it in others. See Engdahl, supra note 36, at 493-501.

184. The developments contributing to the pyramidization of the federal judiciary are detailed in the author's unpublished manuscript referred to in note 126 supra.

185. The steps critical to pyramidization were complete within the first two decades of the nineteenth century. Meanwhile, although it was evident in the jurisprudence of some states by 1820 , see MORTON J. HoRwTt, THE TRANSFORMATION OF AMERICAN LAW 1780-1860, at 1-30 (1977), a conscious instrumentalism did not characterize Supreme Court decisionmaking before the influx of President Jackson's appointees before and after John Marshall's death in 1835.

186. See, e.g., AleXander M. BICKEL, The Least DaNgerous Branch: The SuPREME COURT AT THE BAR OF POLITICS (1962).

187. See Charies L. Black, ThE PEOPLE AND THE CoURT 52-53 (1960).

188. See, e.g., Robert H. Bork, Neutral Principles and Some First Amendment Problems, 47 IND. L.J. 1 (1971); Mark V. Tushnet, Following the Rules Laid Down: A Critique of Interpretivism and Neutral Principles, 96 HARV. L. REV. 781 (1983); Herbert 
ment," 190 the "institutionalization of prophecy,"191 "ethical" arguments, ${ }^{192}$ and various other "unhelpful"193 theoretical contrivances ${ }^{194}$-in order to reconcile ${ }^{195}$ it with democratic. Or republican or even moral postulates, becomes instead (more helpfully) an enterprise to prospect, mine, and refine resources for fashioning persuasive forensic arguments. For many law students and teachers, not to mention practitioners and judges, this might seriously upset the conventional mode of conceiving so-called "constitutional law." There might be other benefits as well. ${ }^{196}$

The wish for certainty, uniformity, and predictability easily seduces us to accept supremacy. But those wished-for goals are unattainable in any event. Even under a tutelage of the coif, we have grown accustomed to "a high degree of unanticipated judicial plasticity." We should not have needed a "Crit" to remind us that "we all can live with fragmented Courts and decisions,",198

Wechsler, Toward Neutral Principles of Constitutional Law, 73 HARV. L. REV. 1 (1959).

189. See, e.g., Richard S. Kay, Adherence to the Original Intentions in Constitutional Adjudication: Three Objections and Responses, 82 Nw. U. L. REv. 226 (1988); cf. Paul Brest, The Misconceived Quest for the Original Understanding, 60 B.U. L. REV. 204 (1980) (discussing the methods of originalism and advocating "nonoriginalist adjudication" over even the most "moderate originalism").

190. See JoHn H. Ely, Democracy AND Distrust: A THEORY of Judicial REVIEW 87-104 (1980); cf. Levinson, supra note 162, at 380-81 (discussing alternative method of constitutional theory).

191. See Michael J. Perry, Noninterpretive Review in Human Rights Cases: A Functional Justification, 56 N.Y.U. L. REv. 278 (1981).

192. See Philip Bobbirt, Constitutional fate 93-177 (1982).

193. See William Van Alstyne, Interpreting This Constitution: The Unhelpful Contributions of Special Theories of Judicial Review, 35 U. FLA. L. REv. 209 (1983). As Professor Van Alstyne noted: "Noninterpreting the only Constitution we are in fact expounding, namely this Constitution, whether because one is disgruntled with its limited wisdom or because some provisions are genuinely intractable, is not an impressive enterprise." Id. at 232. He opined, perhaps too optimistically, that "the historic quest to fashion nonstandard theories of judicial review in constitutional cases has pretty much run its course," id. at 233, and, "I believe that most of it will eventually be seen at a later date as but the academic residue of yet another period in which American constitutional law records its native propensity for instability and rank politicization." Id. at 228. Hurrah!

194. See generally Thomas C. Grey, Do We Have an Unwritten Constitution?, 27 STAN. L. REV. 703 (1975) (discussing noninterpretive adjudication, criticisms lodged against it, and the ramifications of completely eliminating it).

195. Or to proceed boldly without pretending to reconcile. See, e.g., Mark Tushnet, The Dilemmas of Liberal Constitutionalism, 42 OHIO ST. L.J. 411 (1981).

196. It would be redundant to repeat here the seven page "Jurisprudential Epilogue" of my cognate work. See Engdahl, supra note 36, at 504-10.

197. Van Alstyne, supra note 193, at 218.

198. See Tushnet, supra note 188 , at 809 . 
and also with outcomes on urgent points that differ. We have seen them differ, if not quite from case to case, almost from Term to Term, and certainly from "Court" to "Court." If, instead, no pretense of authoritativeness were made, honest agreement might more easily distill on points fairly touched by the Constitution; and, at least, the stakes of pretending more points to be touched by it would diminish. It is a mark of shame, not sophistication, that judicial selection has become the apogee of partisan politics.

Apart from mere habit, what best explains the persistent attachment to judicial supremacy today is not sober reflection on political "science" or the governance arts, but rather the hope of advancing one or another social or political agenda more easily than through democratic political processes. Until "the worm turned," the Supreme Court was esteemed as an instrument of progressive change, not of stability; now, equivalent change in the form of redaction excites cries of "instability" from many, ${ }^{199}$ not because they want stability, but only because they do not want this kind of change.

It is true that the Supreme Court-like other courts-has exercised moral leadership from time to time. But we must remember that Justices are equally capable of ridiculous, ${ }^{200}$ distressing ${ }^{201}$ grave, ${ }^{202}$ and even dreadful ${ }^{203}$ mistakes. Rigorously maining).

199. See, e.g., Payne v. Tennessee, 111 S. Ct. 2597, 2619 (1991) (Marshall, J., dissent-

200. As in, e.g., the Schooner Peggy case, discussed supra note 111 and accompanying text.

201. As in Marbury itself: Applying the mistaken notion that "original" and "appellate" are mutually exclusive categories, the Court created the first great hiatus in Congress's otherwise virtually complete vesting of Article III's jurisdictional scope. The Supreme Court was the only court given jurisdiction by the 1789 Judiciary Act to mandamus federal officials. Thus, in the teeth of Marshall's noble preunise that remedying wrongs is the first duty of government, the very essence of liberty itself, Marbury actually left the injured petitioners with no remedy at all! Contrary to the very premises elaborated in that opinion itself, the effect of Marbury was to make it (for the first time) all but impossible to compel federal officials to perform even ministerial duties mandatorily owed under federal law. For elaboration and documentation of these points, see Engdahl, supra note 162, at 539-43.

202. E.g., "Hans v. Louisiana, 134 U.S. 1 (1890). In Hans, just when citizen suits against states to enforce the Reconstruction Amendments were beginning to appear, the Court officiously rewrote the Eleventh Amendment to foreclose federal question suits by persons against their own states. The persisting stubborn refusal by a majority of the Justices to recognize and rectify this disgrace has too long delayed the development of methods to protect state fiscs more fairly than by simply denying effective redress to mjured persons. See generally David E. Engdahl, Immunity and Accountability for Positive Govemmental Wrongs, 44 U. CoLO. L. REV. 1, 60-75 (1972).

203. E.g., Dred Scott v. Sanford, 60 U.S. (19 How.) 393 (1857) (holding that a slave 
taining judicial independence, in addition to facilitating efforts at justice for particular parties (with as much opportunity for appellate review as Congress might choose to afford), invites reflective consideration of important issues in published opinions which might enrich philosophical and political debate, might light the path of enlightenment, and might even persuade. Remembering, however, that the only necessary impact of a judicial decision is within the limits of a particular "case" can help prevent the occasional instances of judicial unwisdom working untoward harm.

Authoritarianism is a very high price to pay, even for desirable change; and its currency cannot buy the stability that emerges from dialogue and assent. Rejection of that price by no means threatens chaos: On human rights issues, the alternative to judicial supremacy is not social or moral stagnation, but democratic moral growth. On organic constitutional issues, ${ }^{204}$ it is not anarchy, but reasoned dialogue and practical accommodation. On both, rejection of judicial authoritarianism redeems the great rhetorical potential $^{205}$ of written constitutions from the tyrannous constraint of stare decisis.

Romanticizers of judicial supremacy during the recently ended period of liberal judicial activism were fond of saying that the Constitution must keep up with the times. Jefferson had a very similar view; but he thought better than to leave the "keeping up"

brought into a free state is not a citizen and therefore is not entitled to privileges of citizenship, including bringing suit in federal court).

204. Enumerated powers doctrine, intergoverninental relations, and the separation of powers are examples of organic constitutional issues.

205. Musing to Jefferson in 1788 about the desirability of a written "bill of rights" for the federal Constitution (before Jefferson had suggested to him that it could give a "legal check" to the judiciary), James Madison wrote:

What use then ... can a bill of rights serve in popular Governments? I answer the two following which though less essential than in other Governments, sufficiently recommend the precaution. 1 . The political truths declared in that solemn manner acquire by degrees the character of fundamental maxims of free Government, and as they become incorporated with the national sentiment, counteract the impulses of interest and passion. 2. Altho' it be generally true ... that the danger of oppression lies in the interested majorities of the people rather than in usurped acts of the Government, yet there may be occasions on which the evil may spring from the latter sources; and on such, a bill of rights will be a good ground for an appeal to the sense of the community.

Letter from Madison to Jefferson, supra note 11, at 298-99.

This rhetorical potential of written constitutions sometimes actually depends substantially upon the absence of specificity and authoritative particularity as to the scope and precise meaning of constitutional provisions-as Madison explained well enough in that same 1788 letter to Jefferson. Id. at 299-300. 
entirely in the hands of unrepresentative judges and their privileged professional minions. Immediately after observing that "departments" of the government already had sometimes followed opposing views on constitutional points, "\& no ill ensue," 206 Jefferson added:

[T] The constitution moreover, as a further security for itself, ... has provided for it's own reintegration by a change of the persons exercising the functions of those department. Succeeding functionaries have the same right to judge of the conformity or non-conformity of an act with the constitution, as their predecessors who past it. ${ }^{207}$

Jefferson had faith enough in the good sense of even persons not schooled in the niceties of law that he declined to restrict this "right" the Constitution provided "as a further security for itself" to judicial functionaries alone.

The Jeffersonian view does not subject the Constitution to change with every political wind, however. Jefferson himself wrote in 1801 that "uniform decisions indeed, sanctioned by successive functionaries, by the public voice, and by repeated elections would so strengthen a construction as to render highly responsible a departure from it." ${ }^{208}$ Years more of practical experience affirmed Jefferson's confidence that practical good sense, accommodation, and responsible judgment would tend to stabilize construction on most points and obviate contradictions and impasse; he wrote in 1815 , "[T]he prudence of the public functionaries, and authority of public opinion, will generally produce accomoda-tion."209 And Georgia's Jeffersonian Senator Abraham Baldwin noted in 1802

206. See supra text accompanying note 72. Jefferson later gave these examples: Such an instance of difference occurred between the judges of England (in the time of Lord Holt) and the House of Commons, but the prudence of those bodies prevented inconvenience from it. So in the cases of Duane and of William Smith of South Carolina, whose characters of citizenship stood precisely on the same ground, the judges in a question of meum and tuum which came before them, decided that Duane was not a citizen; and in a question of membership, the House of Representatives, under the same words of the same provision, adjudged William Smith to be a citizen. Yet no inconvenience has ensued from these contradictory decisions.

Letter from Jefferson to Torrance, supra note 71, at 304-05. He omitted to mention, on that occasion, his own and Congress's actions pardoning and compensating persons convicted under the Sedition Act.

207. See 3 BEVERIDGE, supra note 72, at 605.

208. Id.

209. Letter froin Jefferson to Torrance, supra note 71, at 304. 
that written constitutions "do not settle everything; questions will arise in administering them, which occasion honest doubts .... Many questions of this kind have already been so far settled by practice on our Constitution, that they have rarely been stirred of late."210 As to the questions thus settled (virtually all of which in his day had been settled extrajudicially), Baldwin added: "Those occasions had been represented at the time, as very threatening to the Government; . . . and they did not, in the end, prove so disastrous as had been predicted ....."211

Stability and permanence require accommodation and settlement by practice of many points for long periods of time; moral, social, and political "progress" or adaptation to new circumstances sometimes require "reintegration" of (or to) the Constitution. Perhaps the difference most important for today between the "Jeffersonian" view and the thesis of judicial supremacy has to do with which and how many of the nation's citizens and officials should be deemed entitled to participate in these processes of accommodation and reintegration.

It demeans too much the good sense of a relatively free people to think their institutions must founder unless a handful of lawyers play final arbiter of the great political and social disputes their developing culture has not yet substantially resolved. John Marshall held no such miserable opinion; nor should we. ${ }^{212}$

210. 11 ANNALS OF CONG. 105 (1802).

211. Id.

212. It might well be that the "Jeffersonian" concept of judicial review will prove attractive in international practice, whether or not its utility for domestic American practice is recognized and recovered. This is suggested by Geoffrey R. Watson, Constitutionalism, Judicial Review, and the World Court, 34 HARV. INT'L I.J. (forthcoming Feb. 1993). 